\title{
BAMBARA GROUNDNUT RHIZOBACTERIA ANTIMICROBIAL AND BIOFERTILIZATION POTENTIAL
}

\author{
Caroline F. Ajilogba ${ }^{1,2}$, Olubukola O. Babalola ${ }^{1 *}$, Patrick Adebola ${ }^{3,4}$ and Rasheed \\ Adeleke $^{5}$
}

${ }^{1}$ Food Security and Safety Niche Area, Faculty of Natural and Agricultural Science, North-West University, Mmabatho, Mafikeng 2735, South Africa. olubukola.babalola@nwu.ac.za

${ }^{2}$ Agricultural Research Council-Soil, Climate and Water, Private Bag X79, Pretoria, 0001, South Africa

${ }^{3}$ Agricultural Research Council-Vegetable and Ornamental Plants, Private Bag x 293, Pretoria, 0001 South Africa

${ }^{4}$ International Institute of Tropical Agriculture (IITA)-Abuja Station, PMB 82, Beside Old Water Works, Kubwa, 901101, FCT, Abuja

${ }^{5}$ Faculty of Natural and Agricultural Science, North-West University Potchefstroom Campus, Potchefstroom, 2520, South Africa

\begin{abstract}
Bambara groundnut, an underutilized crop has been proved to be an indigenous crop in Africa with the potential for food security. The rhizosphere of Bambara groundnut like other legumes contains several important bacteria that have not been explored for their plant growth-promoting properties. The aim of this research was to determine the potentials of rhizobacteria from Bambara groundnut soil samples as either biofertilizer or biocontrol agents or both to help provide sustainable agriculture in Africa and globally. Analyses of Bambara groundnut rhizospheric soil samples included chemical analysis such as nitrogen content analysis using extractable inorganic nitrogen method as well as cation exchangeable capacity using ammonium acetate method. Plant growth-promoting properties of isolated rhizobacteria tested include indole acetic acid, hydrogen cyanide, phosphate solubilization, 1-aminocyclopropane-1-carboxylate and ammonia production activities using standard methods. In addition, antifungal assay dual culture method was used to analyze the biocontrol properties of the isolates. Phylogenetic analysis using 16S rRNA was also carried out on the isolates. Isolated rhizobacteria from bambara groundnut rhizosphere were cultured. All the isolates were able to produce ammonia and 1-aminocyclopropane-1-carboxylate while 4.65\%, $12.28 \%$ and $27.91 \%$ produced Hydrogen cyanide, Indole acetic acid and solubilized phosphate respectively, making them important targets as biocontrol and biofertilizer agents. The growth of Fusarium graminearum was suppressed in vitro by $6.98 \%$ of the isolates. Plant growth promoting activities of rhizobacteria from
\end{abstract}


bambara groundnut rhizosphere reveals that it has great potentials in food security as biofertilizer and biocontrol agent against fungal and bacterial pathogens.

Keywords: Bambara groundnut, biocontrol, biofertilizer, plant growth-promoting rhizobacteria, rhizosphere

\subsection{Introduction}

The use of chemicals to inhibit the growth of pathogenic microorganisms in plant disease control has been a global issue. Research for more healthy environmental control methods have led to biocontrol and biofertilization. Rhizospheric soils of legume crops have been considered a reservoir for plant growth promoting rhizobacteria (PGPR). Bambara groundnut (Vigna subterranean L. Verdc), a legume crop, is one of the neglected and underutilized (NUS) species. The term 'NUS' is used to mean wild species of plant which are non-commodity cultivated. They form part of a large agro biodiversity portfolio that are not used as a result of an array of factors such as agronomic, genetic, economic, social and cultural factors [1]. They are traditionally grown by subsistence farmers in their various localities where they are useful in supporting and securing nutrition in local communities in order to meet their socio-cultural needs and traditional uses. They have been largely ignored by research and development and so there is no competition for them compared to other well-established major crops. This results in the loss of both their diversity and traditional knowledge. It is a food known as a balanced diet as it contains the right proportion of protein $(16.25 \%)$, carbohydrate (63\%) and fats $(6.3 \%)$ [2]. The protein is high in both lysine (6.6\%) and methionine $(1.3 \%)$ [3]. Because of its richness in protein and the fact that it is nutritious, it is a source of food security especially for small scale farmers and small households [4]. Bambara groundnut is also very rich in micronutrients such as potassium, calcium and iron with a high proportion of fiber [5]. There are different varieties with varying mineral composition for example the red varieties contains iron twice as much as the cream variety making it quite suitable for mineral deficient in iron [4]. It was observed that fermentation of bambara groundnut helped to improve its mineral composition which invariably reduced the different factors that inhibited nutrient utilization such as trypsin, oxalate, phytic and tannic acid [6].

Bambara groundnut has the ability to grow under different climatic and soil conditions that are harsh and extreme thus making it suitable to be grown in semi-arid lands. The soil rhizosphere of legumes which include bambara groundnut has been indicated to enhance plant growth and also for controlling plant pests and diseases. Such beneficial attributes are associated with a host of rhizobacteria that inhabit this rhizosphere and are also sometimes referred to as PGPR. Examples of such bacteria include Bacillus spp, Actinomycetes, spp Pseudomonas spp, Burkholderia spp and Rhizobium spp [7]. The diversity of these microbial communities is driven by plant-microbe activities such as organic compound secreted by plants as well as availability and quantity of nutrients released by microbes. These interactions also play a crucial 
influence on the health, growth, pest and disease susceptibility of the plant as well as the health of the soil [7].

Plant growth-promoting rhizobacteria (PGPR) also promote plant growth directly by producing phytohormones such as IAA and HCN. Sometimes they enhance iron chelation (siderophore production) and supply of nutrients such as phosphorus (phosphate solubilization) and nitrogen (nitrogen fixation) to also promote plant growth. They are well known to participate in biofertilization, which involves enriching rhizospheric soil, making nutrients available to the plants as well as aiding the plants in nutrient uptake and the subsequent use of the nutrients for metabolic processes by the plants [8]. They have also been found to help in biocontrol of plant pests and diseases by suppressing and/or inhibiting the growth of pathogens in/on plants [9]. As new pathogens causing plant diseases are being identified, there is the need to find better bioalternatives that have not been harnessed but have prospects. The rhizosphere of bambara groundnut has not been explored like other legumes for rhizobacteria that are important in biofertilization and biocontrol. This study aimed at evaluating the rhizobacteria found in the rhizosphere of Bambara groundnut for their biofertilization and biocontrol potentials as a tool for food security.

\section{0 Materials and methods}

\subsection{Planting of Bambara groundnut}

The propagation of Bambara groundnut was through seeds on level seedbed or ridges where the soil is wet. Seeds from two different landraces VL and VBR were planted on seedbeds in plots that are $50 \mathrm{~cm}$ apart and spacing between seed holes on each plot was $50 \mathrm{~cm}$ apart (Fig. 1a and Fig 1b). Seeds were planted 3-4 $\mathrm{cm}$ deep in the soil. Twenty-five (25) plots were cultivated for each replication and the experiment was repeated thrice.

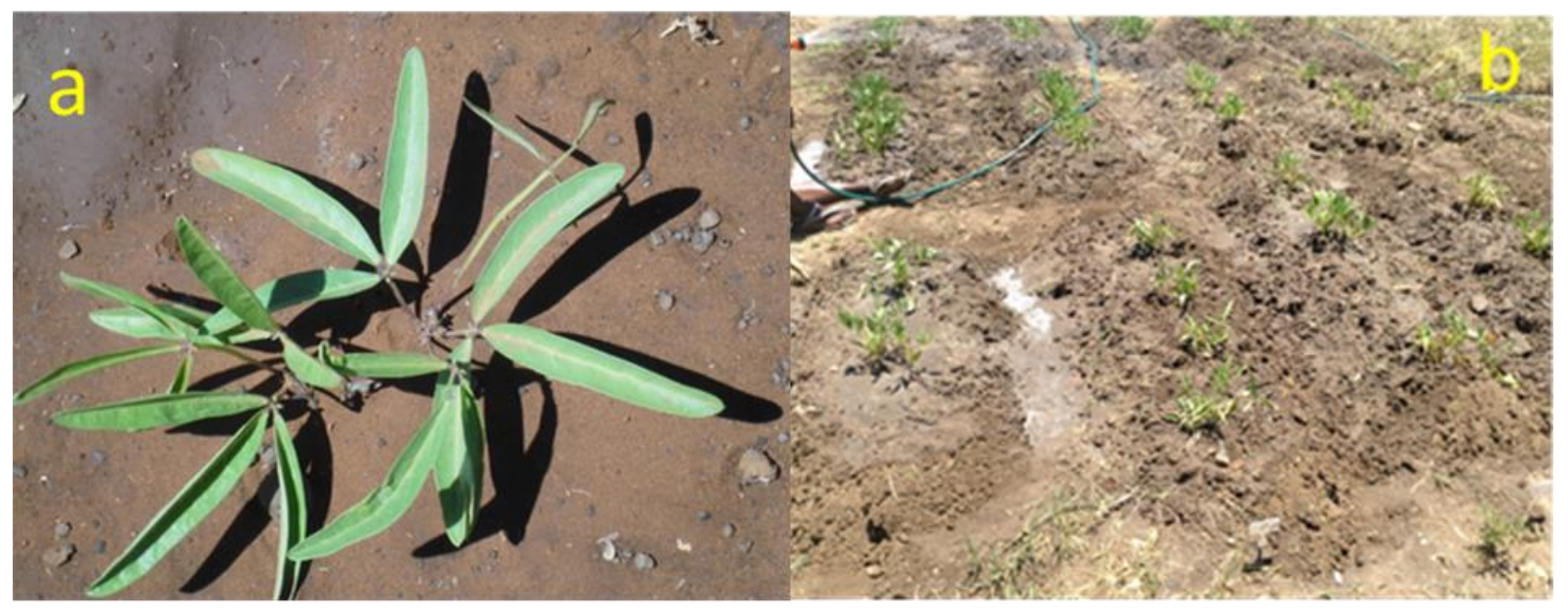

Figure 1: Plot showing Bambara groundnut 2 weeks after planting ( $a$ and $b$ ) 


\subsection{Soil sampling and collection}

Soil samples were collected from field trials during the planting period between October 2014 and March 2016 from the North-West University Agricultural Farm, Mafikeng Campus (Lat. 257 ${ }^{\prime} 91^{\prime \prime}$ Long. $\left.25^{\circ} 61^{\prime} 84^{\prime}\right)$ Mafikeng, South Africa. Four soil samples were collected randomly from the uprooted Bambara groundnut root rhizosphere at four weeks interval from bulk soil before planting for 16 weeks corresponding to different growth stages of the plant. Twenty four (24) soil samples were collected in all to a depth of 15 $\mathrm{cm}$ per sample. Samples were collected in triplicates from the rhizosphere of two different landraces and were stored at $4^{\circ} \mathrm{C}$ until ready for use.

\subsection{Soil Analysis}

According to the International Standard Organization (ISO) standard 11464, the samples were prepared for analysis by drying at room temperature, pulverized, and sieved through a $2 \mathrm{~mm}$ sieve. All glassware used for soil analyzes were washed thoroughly, soaked in $20 \%$ nitric acid and rinsed with deionized water to prevent the presence of impurities. The selected physical and chemical parameters of the samples were analyzed using standard laboratory procedures [10].

All soil analysis were repeated twice.

\subsubsection{Physical and chemical analysis of samples}

\subsubsection{Determination of CEC and extractable cations}

Exchangeable cation was determined using the ammonium acetate method [11]. Sample of the soil was aliquot and sieved using a 2-mm screen and allowed to air dry (at a temperature of $\leq 60^{\circ} \mathrm{C}$ ). Ten $(10) \mathrm{g}$ of the air-dried soil was placed in a 500-mL Erlenmeyer flask and $250 \mathrm{~mL}$ of neutral, $1 \mathrm{~N} \mathrm{NH}_{4} \mathrm{OAc}$ was added to it. The flask was thoroughly shaken and allowed to stand overnight. The soil was filtered with light suction using a 55-mm Buchner funnel. The soil was leached with the neutral $\mathrm{NH}_{4} \mathrm{OAc}$ reagent until no test for calcium can be obtained in the effluent solution. The soil was then leached four times with neutral $1 \mathrm{~N}$ $\mathrm{NH}_{4} \mathrm{Cl}$ and once with $0.25 \mathrm{~N} \mathrm{NH}_{4} \mathrm{Cl}$.

The electrolytes were washed with $99 \%$ isopropyl alcohol having a volume of between 150 to $200 \mathrm{~mL}$. When the test for chloride in the leachate (use $0.10 \mathrm{AgNO}_{3}$ ) became negligible, the soil was allowed to drain thoroughly. The adsorbed $\mathrm{NH}_{4}$ was determined by the aeration method [12].

\subsubsection{Nitrogen analysis of soil samples}

Soil samples were dried at $80^{\circ} \mathrm{C}$, ground to a powder and $1 \mathrm{~g}$ analysed for nitrogen $(\mathrm{N})$ by Kjeldahl digestion [13]. 


\subsubsection{Determination of nitrate composition}

Nitrate contents of the samples were determined using the equilibrium extraction method. Ten (10) $g \leq 2.0$ $\mathrm{mm}$ of air-dry soil was placed into a $250 \mathrm{~mL}$ wide mouth extraction bottle and $100 \mathrm{~mL}$ of $0.1 \mathrm{~mol} \mathrm{dm}^{-3}$ of $\mathrm{KCl}$ was added, stoppered and shaken for $30 \mathrm{~min}$ on a shaker. The solution obtained was filtered to get a clear extract and the nitrate contents were determined in the clear extract.

\subsubsection{Determination of $\mathrm{pH}$ and redox potential}

Ten (10) $\mathrm{g}$ of soil was weighed and mixed with $25 \mathrm{~mL}$ of distilled water to obtain ratio 1:2.5 (m:v) soilwater suspension and left to shake for $1 \mathrm{~h}$ and left standing overnight for $\mathrm{pH}$ measurement with a $\mathrm{pH}$ meter Jenway $3520^{\mathrm{TM}}$ (Lasec, South Africa). The pH meter was standardized using calibration buffer 4, 7 and 9. The combined electrode was inserted into supernatant and $\mathrm{pH}$ values and redox potential of the samples was recorded, electrode was washed with distilled water after each reading.

\subsubsection{Determination of organic matter}

Organic carbon was determined by Walkley-Black method [14]. One (1) g of air-dried sample was weighed and $10 \mathrm{~mL}$ of $1 \mathrm{~N}$ potassium dichromate solution was added followed by addition of $20 \mathrm{~mL}$ concentrated sulphuric acid and the beaker was swirled to mix the suspension. The solution was left undisturbed and allowed to stand for $30 \mathrm{~min}$ and $200 \mathrm{~mL}$ deionized water and $10 \mathrm{~mL}$ concentrated orthophosphoric acid was added. Twelve (12) drops of diphenylamine indicator $(1 \mathrm{~g}$ diphenylamine in $100 \mathrm{~mL}$ concentrated sulfuric acid) was added with continuous stirring on a magnetic stirrer and finally the mixture was titrated with $0.5 \mathrm{M}$ ferrous ammonium sulphate until a colour change from violet-blue to green was observed. A blank solution was also prepared in which no sample was added. The percentage of organic matter was used to calculate the organic carbon content by using the conversion factor 1.724 and the fact that $58 \%$ of the soil organic matter is the average content of carbon [14]. This calculation is given below;

Percentage organic matter in soil is calculated as written below:

$\begin{array}{ll}\text { Molarity }(\mathrm{M})= & \frac{10}{\text { vblank }}=10 / 9.6\end{array}$

$\%$ oxidizable organic carbon $=\frac{[\text { vblank-vsample }] \times 0.3 \times M}{w t}$

( wt=weight of air-dried soil $=1 \mathrm{~g}$ )

$\%$ total organic Carbon $(\mathrm{w} / \mathrm{w})=1.334 \mathrm{x} \%$ oxidizable organic carbon

$\%$ organic matter $(\mathrm{w} / \mathrm{w})=1.724 \times \%$ total organic Carbon

\subsection{Preparation of soil samples for bacterial isolation}

Soil samples from the rhizosphere of Bambara groundnut were collected. Samples were prepared according to Abdulkadir and Waliyu [15] and placed into sterile 50-mL Falcon tubes (Becton Dickson Paramus, N.J) and kept on ice or at $4^{\circ} \mathrm{C}$ until it was needed (within 3 days). 


\subsection{Culturing and isolation of bacteria from soil samples}

Isolation and enumeration of bacteria present in the soil sample were performed by serial dilution plate technique using tryptone soy agar (TSA) and the procedure of Cavaglieri, Orlando, Rodriquez, Chulze and Etcheverry [16]. A 10-fold dilution series was prepared from the rhizospheric soil of bambara groundnut in sterile distilled water and $0.5 \mathrm{~mL}$ from the selected dilution was spread plated on the already set tryptic soy agar (TSA). Two (2) loopfuls of each of the bacteria from 3-day old cultures on TSA were each transferred separately to $50 \mathrm{~mL}$ tryptic soy broth (TSB) medium and incubated overnight at $28 \pm 2{ }^{\circ} \mathrm{C}$. A loopful from each TSB bacterial inoculum was streaked on prepared TSA to have pure isolates from each broth culture. Viability was confirmed by standard plate count method using tryptone soy broth plus $2 \%$ agar (TSBA). These inocula were prepared in order to use them in vitro for testing the antifungal and biocontrol activities of the isolates.

\subsection{PGPR and biochemical analysis of bacteria isolates}

\subsubsection{Detection of hydrogen cyanide (HCN) production}

Bacterial isolates were screened for the production of hydrogen cyanide $(\mathrm{HCN})$ production according to the methodology previously described by Castric [17]. Bacterial cultures were streaked on nutrient agar medium containing $4.4 \mathrm{~g}$ per liter of glycine. Picric acid solution ( $0.5 \%$ in $2 \%$ sodium carbonate) was prepared and Whatman filter paper No 1 was soaked in it and was placed inside the lid of a plate which was sealed with parafilm. After plates were incubated at $30^{\circ} \mathrm{C}$ for 4 days, production of $\mathrm{HCN}$ was observed by the light brown to dark brown colour that developed and no colouration development indicated negative activity.

\subsubsection{Determination of indole acetic acid (IAA) production}

Fifty (50) $\mathrm{mL}$ of nutrient broth (Merck) containing $0.1 \%$ (D) L-tryptophan were inoculated with $500 \mu \mathrm{L}$ of $24 \mathrm{~h}$ old bacterial cultures and incubated in refrigerated incubator Shaker at $30^{\circ} \mathrm{C}$ and $180 \mathrm{rpm}$ for $48 \mathrm{~h}$ in the dark. The bacterial cultures were then centrifuged at $10,000 \mathrm{rpm}$ for $10 \mathrm{~min}$ at $4^{\circ} \mathrm{C}$ [18].

An aliquot of $1 \mathrm{~mL}$ of supernatant was transferred into a fresh tube to which $50 \mu \mathrm{L}$ of $10 \mathrm{mM}$ orthophosphoric acid and a $2 \mathrm{~mL}$ of Salkowski reagent comprising ( $1 \mathrm{~mL}$ of $0.5 \mathrm{M} \mathrm{FeCl}_{3}$ in $50 \mathrm{~mL}$ of $35 \%$ $\mathrm{HCIO}_{4}$ ) were added. The mixture was incubated at room temperature for $25 \mathrm{~min}$. The development of a pink colour indicated the presence of indole acetic acid [19]. The absorbance of the pink solution from each isolate was measured and recorded at $530 \mathrm{~nm}$ using spectrophotometer (Thermo Spectronic, Merck, SA).

\subsubsection{Determination of Phosphate solubilisation (PS)}

Bacterial isolates were spot inoculated on Pikovskaya agar medium plates. The plates were incubation at $28^{\circ} \mathrm{C}$ for 7 days. Phosphate solubilization activity was observed as clear zone around the colonies while no zone was considered negative activity [20]. 


\subsubsection{Detection of ammonia $\left(\mathrm{NH}_{3}\right)$ production}

Peptone water was used to determine ammonia production of bacterial cultures. Freshly grown cultures were inoculated into $10 \mathrm{~mL}$ peptone water and incubated for $48-72 \mathrm{~h}$ at $30^{\circ} \mathrm{C}$. Nessler's reagent $(0.5 \mathrm{~mL})$ was added in each tube after incubation and positive test was observed as brown to yellow colour development while negative activity was observed with no colour development [21].

\subsubsection{Determination of 1-aminocyclopropane-1-carboxylate (ACC)}

This procedure was carried out according to the protocol of Li et al., 2011. Ninhydrin reagents were prepared and five working concentrations of ACC were used which are 0.05, 0.15, 0.2, 0.3 and $0.5 \mathrm{mmol}^{-}$

${ }^{1}$ for colorimetric assay using the 96-wells PCR plates. Absorbance was read at $570 \mathrm{~nm}$.

\subsubsection{Catalase activity}

A sterile toothpick was used to mix $48 \mathrm{~h}$ old bacterial colonies placed on a clean glass slide to which a drop of $3 \%$ hydrogen peroxide was added. The effervescence that follows indicated catalase positive activity while no effervescence indicated negative activity.

\subsubsection{Assay for protease production}

Extracellular protease production was assayed according to Maurhofer, Keel, Haas and Défago [22]. Spot inoculation of each bacterial isolate on skim milk agar plate was carried out and incubated at $37^{\circ} \mathrm{C}$ for 24 h. Development of halo zone around the bacterial colony was considered as a positive test for protease production while absence of halo zone was considered negative test.

\subsubsection{Oxidase activity}

Oxidase activity was determined by using the filter paper spot method [23]. Kovács oxidase reagent (1-2 drops) was added to $24 \mathrm{~h}$ old culture on a small piece of filter paper. Change in colour to dark purple within 60 to $90 \mathrm{~s}$ was considered as oxidase positive test while absence of colour change indicated negative activity.

All analysis were repeated twice

\subsection{Antifungal effect assay}

Potato dextrose agar (PDA) medium was used as the medium to assay for the antifungal activities of 8 isolates against $F$. graminearum which is a toxin producing fungi and pathogenic to man, animals and plants. This was carried out by inoculating the pathogenic fungi at the centre of the medium and then streaking the isolates on the medium $3 \mathrm{~cm}$ away from the fungi. The clear zones between isolates and fungi after incubation for 4 to 7 days at room temperature indicated antagonist interaction between them.

\subsubsection{Antibacterial effect assay}

Antagonistic activity of isolates against B. cereus and E. feacalis was carried out. B. cereus is a food poisoning pathogen worldwide with serious health implication, so it is very important in the food industry 
and agriculture [24]. E. feacalis is among the diverse type of bacteria capable of causing infection in man, animals and plants causing death of plant within 7 days [25]. They were screened by using a perpendicular streak method (Parthasarathi et al., 2010). In perpendicular streak method, Luria Bertani agar (Merck) was used and each plate was streaked with test bacterial isolates at the centre of the plate and incubated at $30^{\circ} \mathrm{C}$ for $48 \mathrm{~h}$ to allow optimum growth. Later, $24 \mathrm{~h}$ fresh sub-cultured isolated bacteria were prepared and streaked perpendicular to the test isolates and incubated at $37^{\circ} \mathrm{C}$ for $24 \mathrm{~h}$. The experiment was carried out in triplicate.

\subsection{Isolation of genomic DNA}

Genomic DNA of all isolates was extracted using ZR soil Microbe DNA MiniPrep ${ }^{\mathrm{TM}}$ (Zymo Research, USA) extraction kit. Bacterial cultures were grown in $10 \mathrm{~mL}$ of Luria Bertani broth (Merck) at $37^{\circ} \mathrm{C}$ for 24 $\mathrm{h}$ and then centrifuged at 10,000 rpm (Universal Z300K model centrifuge; HERMLE Labortechnik, Germany) for $5 \mathrm{~min}$. The bacterial pellets were resuspended in $200 \mu \mathrm{L}$ of distilled water and transferred to ZR Bashing Bead ${ }^{\mathrm{TM}}$ lysis tube and $750 \mu \mathrm{L}$ lysis solutions were added to the tube. The bashing bead was secured in a bead beater fitted with a 2-mL tube holder FastPrep® 24 and processed at a maximum speed for $5 \mathrm{~min}$. The ZR BashingBead ${ }^{\mathrm{TM}}$ lysis tube was centrifuged in a microcentrifuge at $10,000 \times \mathrm{g}$ for $1 \mathrm{~min}$, $400 \mu \mathrm{L}$ of supernatant was transferred to a Zymo-Spin ${ }^{\mathrm{TM}}$ IV Spin Filter in a collection tube and was centrifuged at 7,000×g for $1 \mathrm{~min}$ and 1,200 $\mu \mathrm{L}$ of Soil DNA Binding Buffer was added to the filtrate in the collection tube. Eight hundred (800) micro litres of the mixture of the binding buffer and filtrate was transferred to a Zymo-Spin ${ }^{\mathrm{TM}}$ IIC Column in a collection tube and centrifuged at 10,000×g for $1 \mathrm{~min}$. Two hundred (200) $\mu \mathrm{L}$ of DNA Pre-Wash Buffer was added to the Zymo-Spin ${ }^{\mathrm{TM}}$ IIC column in a new collection tube and centrifuged at 10,000×g for 1 min. Five hundred (500) $\mu \mathrm{L}$ soil DNA Wash Buffer was added to the Zymo-Spin ${ }^{\mathrm{TM}}$ IIC Column in a new collection tube and centrifuged at 10,000xg for $1 \mathrm{~min}$. The ZymoSpin ${ }^{\mathrm{TM}}$ IIC Column was transferred to a clean $1.5 \mathrm{~mL}$ micro-centrifuge tube and $100 \mu \mathrm{L}$ DNA Elution Buffer was added directly to the column matrix. The tube was centrifuged at $10,000 \times \mathrm{g}$ for $30 \mathrm{~s}$ to elute the DNA.

\subsection{PCR Amplification targeting the 16S rRNA}

PCR was carried out in $25 \mu \mathrm{L}$ reaction volumes. Each reaction contained $12.5 \mu \mathrm{L}$ of PCR master mix, 0.5 $\mu \mathrm{L}$ of primer, $11 \mu \mathrm{L}$ of nuclease free water and $1.0 \mu \mathrm{L}$ of DNA template. The $16 \mathrm{~S}$ rDNA gene was amplified using the universal bacterial primers F1 (5'-GAGTTTGATCCTGGCTCAG-3') and R2 (5'GWATTACCGCGGCKGCTG-3') (Maynard et al 2005). PCR was performed using a DNA Engine DYAD ${ }^{\mathrm{TM}}$ Peltier thermal cycler (Bio-Rad). The PCR program used was an initial denaturation at $95^{\circ} \mathrm{C}$ for $5 \mathrm{~min}$, followed by 35 cycles of denaturation at $94^{\circ} \mathrm{C}$ for $30 \mathrm{~s}$, annealing at $62^{\circ} \mathrm{C}$ for $30 \mathrm{~s}$ and extension at $72^{\circ} \mathrm{C}$ for $1 \mathrm{~min}$, followed by a final extension at $72^{\circ} \mathrm{C}$ for $5 \mathrm{~min}$. 


\subsection{Agarose gel electrophoresis procedure}

One times Tris-Acetate EDTA (1X TAE) buffer was prepared by adding $4900 \mathrm{~mL}$ distilled water to 100 $\mathrm{mL}$ of 50X TAE $(375 \mathrm{~mL}$ of Tris-Cl, $28.55 \mathrm{~mL}$ of acetic acid, $50 \mathrm{~mL}$ of EDTA and $46.45 \mathrm{~mL}$ distilled water) and filled in the electrophoresis tank. $1.5 \%$ agarose gel ( $4.5 \mathrm{~g}$ in $300 \mathrm{~mL}$ of $1 \mathrm{X}$ TAE buffer) was prepared by melting in microwave until boiling. Once the agarose was dissolved, it was allowed to cool to $\sim 45^{\circ} \mathrm{C}$ before pouring into the casting mold. Before pouring the agarose gel, combs of desired sizes were inserted into the tray in such a way that no bubbles were caught under the teeth. After the gel had cooled, the combs were gently removed. The gel was placed in the electrophoresis tank to which $150 \mu \mathrm{L}$ ethidium bromide has been added to $1.5 \mathrm{~L}$ buffer to cover it to a depth of about $1 \mathrm{~cm}$. DNA samples were prepared by mixing $10 \mu \mathrm{L}$ of the PCR reaction mixture with $10 \mu \mathrm{L}$ of $1 \mathrm{X}$ loading buffer in 1:1 ratio on sterile parafilm. Twenty (20) $\mu \mathrm{L}$ samples were loaded into each well in the gel with a sterile micropipette and taking care not to cross-contaminate the wells. Six (6) $\mu \mathrm{L}$ of molecular marker (1 kb DNA ladder (Fermentas)) was loaded in the first and the last wells of each comb. The voltage was set to $80 \mathrm{~V}$ and top cover was attached, making sure that the polarity of the preparation was placed correctly. After about $1 \mathrm{~h}$ when the loading dye had migrated to the mid-point of the gel, the power was turned off and the gel removed. DNA fragments were visualized by removing the gel slab from the tray and placing it on a UV trans- illuminator. The outcome of running the gel was recorded/captured using Chemidoc ${ }^{\mathrm{TM}} \mathrm{MP}$ imaging system (Bio-Rad USA).

\subsection{Sequencing and phylogenetic analysis}

The Sequencing of the purified PCR products was conducted at facilities of Inqaba Biotechnical Industrial (Pty) Ltd, Pretoria, South Africa using ABI PRISM® 3500XL DNA Sequencer (Applied Biosystems). Only isolates with best activities in terms of biochemical, biofertilization and biocontrol were sequenced. The chromatograms were edited using Chromas Lite version 2.4 software (Technelysium Pty Ltd 2012) Nucleotide sequences were analyzed and edited by using BioEdit software (Hall, 1999). The obtained 16S rDNA sequences were compared to sequences in the NCBI GenBank database with the Basic Alignment Search Tool (BLAST) (Altschul et al., 1990). Multiple alignments of the sequences were carried out by Mafft programme 7.050 (Katoh, 2013) against corresponding nucleotide sequences of the genus selected isolate retrieved from GenBank. Phylogenetic analyses were conducted using software's in MEGA version 5.2.2 (Tamura et al., 2011). Evolutionary distance matrices were generated as described by (Jukes and Cantor, 1969) and a phylogenetic tree was inferred by the neighbor-joining method (Saitou and Nei, 1987). Tree topologies were evaluated by bootstrap analysis (Felsenstein, 1985) based on 1000 resamplings of the neighbor-joining data set. Manipulation and tree editing were carried out using TreeView (Page, 1996). 


\subsection{Supporting data}

The 16S rDNA gene sequences determined for the bacterial isolates in this study were deposited into the GenBank database and assigned accession numbers (Table 4).

\subsection{Results}

\subsection{Physical and chemical characterization of samples}

\subsubsection{Cation Exchange Capacity (CEC), Nitrate and Nitrogen analysis of soil samples}

In Figure 2, it was observed that the exchangeable cations and the nitrate value followed the same trend in the graph. They decreased from the 4 WAP to the 8 WAP and increased again at the 12 WAP which was the peak and decreased again at the 16 WAP only to start increasing gradually to the time of harvest. The nitrate content ranged between $6.28 \mathrm{mg} / \mathrm{kg}$ at the $8 \mathrm{WAP}$ and $26.16 \mathrm{mg} / \mathrm{kg}$ at the $4 \mathrm{WAP}$. From the $12 \mathrm{WAP}$, it decreased again from $19.06 \mathrm{mg} / \mathrm{kg}$ to $6.40 \mathrm{mg} / \mathrm{kg}$ at the $16 \mathrm{WAP}$ and gradually increased again to the time of harvest to $7.39 \mathrm{mg} / \mathrm{kg}$.

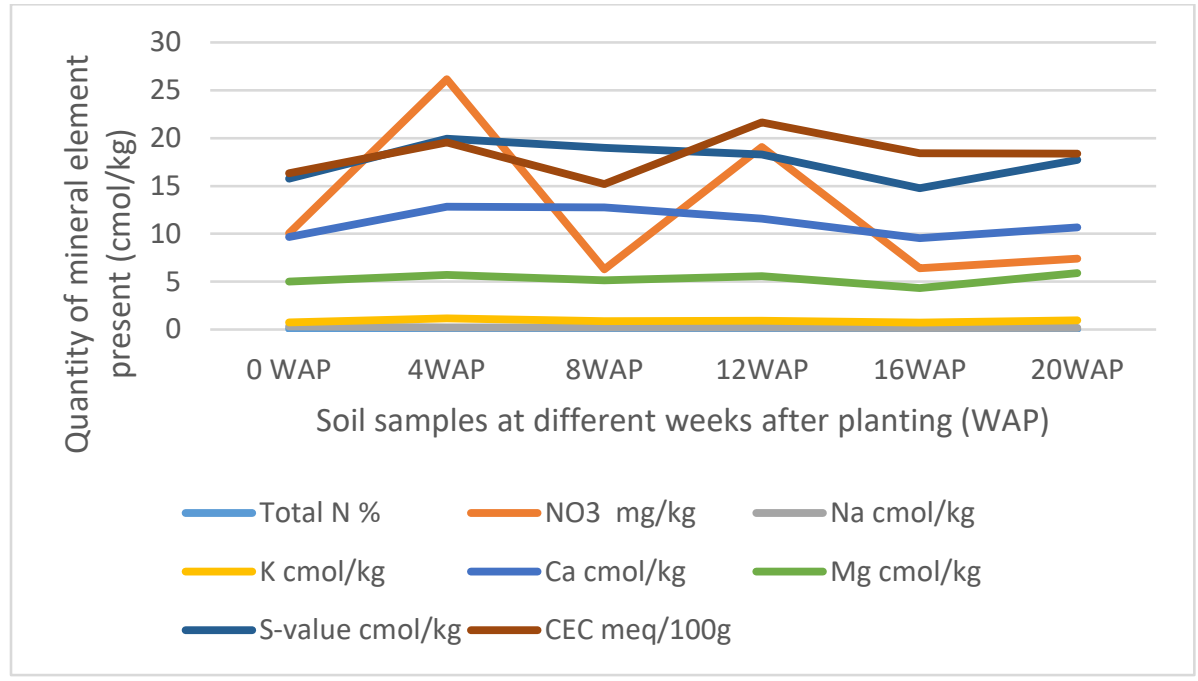

Figure 2: Comparison of different physical and chemical properties of soil samples between 4 and 20 weeks after planting (WAP).

$\mathrm{N}=$ nitrogen, $\mathrm{K}=$ potassium, $\mathrm{Ca}=$ calcium, $\mathrm{Na}=$ =sodium, $\mathrm{Mg}$ =magnesium, $\mathrm{S}$-value shows the mean of the whole graph

All chemical parameters, $\mathrm{N}, \mathrm{K}, \mathrm{Ca}, \mathrm{Na}$ and $\mathrm{Mg}$ increased from zero the original bulk soil to $4 \mathrm{WAP}$. Cation Exchangeable capacity (CEC) and Nitrate followed the same pattern of decreasing from the time of fertilization/flowering (4 WAP) till the $8 \mathrm{WAP}$ and increasing at $12 \mathrm{WAP}$. They gradually decreased from 12 WAP to 16 WAP and gradually increased again to the time of harvest. Samples at 12 WAP had the highest CEC of $21.64 \mathrm{meq} / 100 \mathrm{~g}$. The lowest was $15.19 \mathrm{meq} / 100 \mathrm{~g}$ at $8 \mathrm{WAP}$. Nitrate $\left(\mathrm{NO}_{3}\right)$ was highest at 
$4 \mathrm{WAP}$ and lowest at $8 \mathrm{WAP}$. After 4 WAP, all the minerals kept decreasing gradually until the 16 WAP (which is the time of maturity of seeds) and then started increasing gradually again. The only exceptions are the individual cations $\mathrm{Mg}, \mathrm{Na}, \mathrm{K}$ and $\mathrm{Ca}$ which all followed the same pattern of gradually decreasing up until the $16^{\text {th }}$ week and then gradually increasing afterwards to the time of harvest (Fig. 3 and Fig. 4).

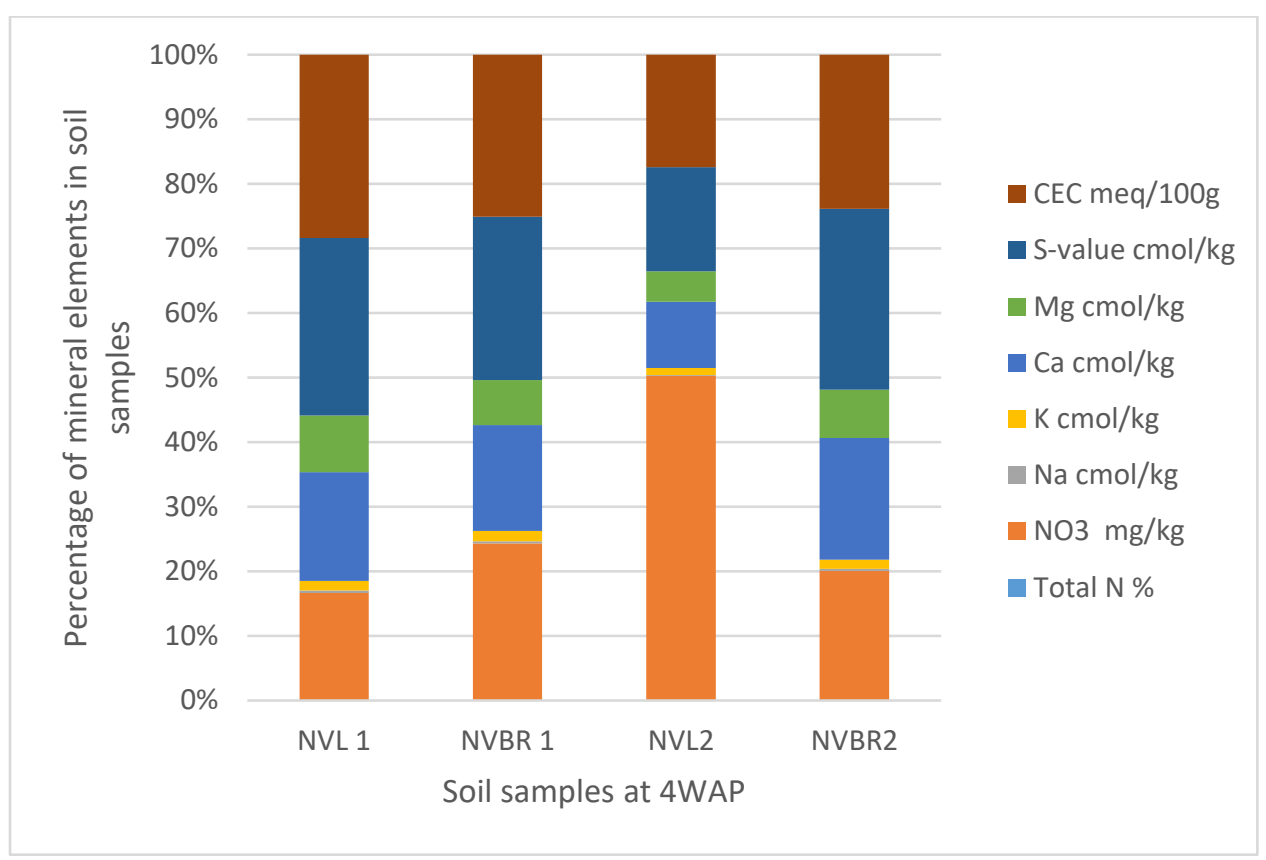

Figure 3: Physical and chemical analysis of soil samples at 4 WAP.

Nitrate (NO3) and CEC were the highest quantity of mineral found in the soil samples and both were found in NVL2 and NVL1 respectively. N=November; VL and VBR=Variety of Bambara from whose root, soil samples (NVL1, NVL2, NVBR1, NVBR2) were taken 


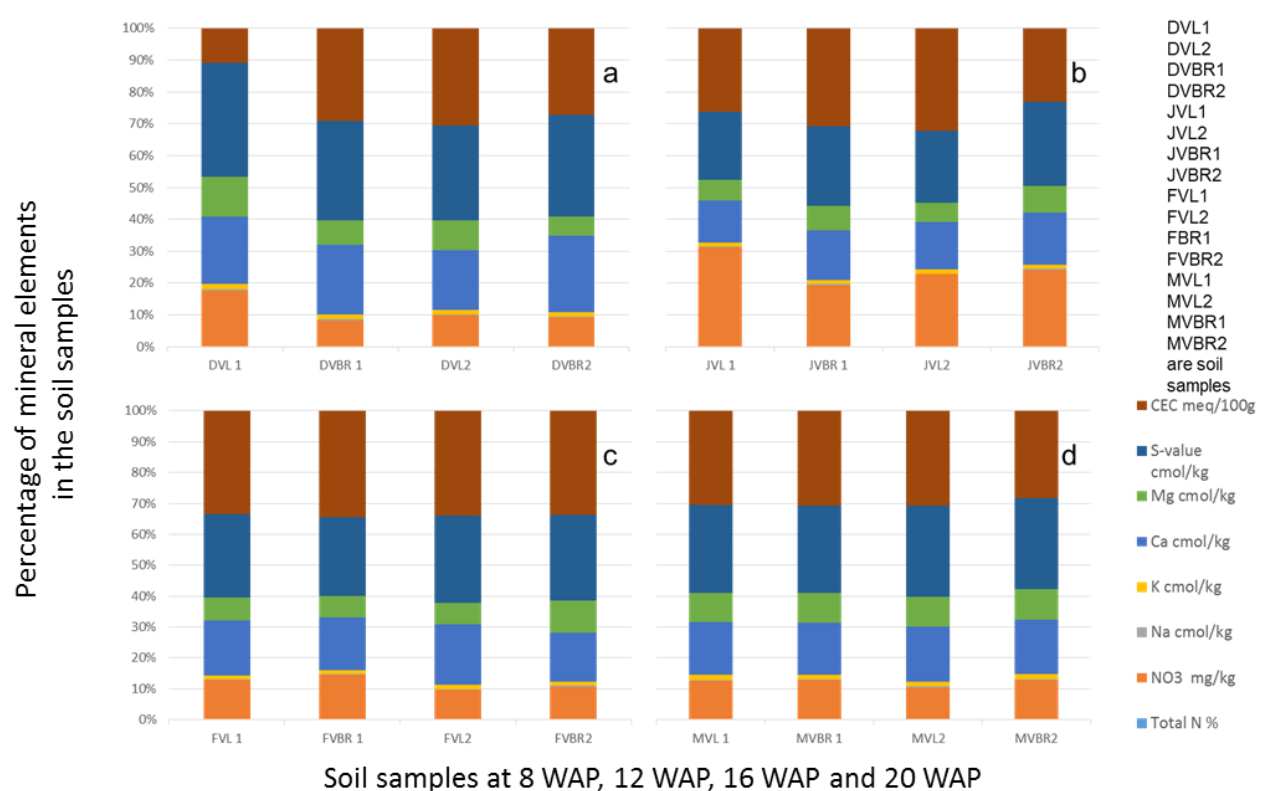

Figure 4: Physical and chemical analysis of soil samples at 8, 12, 16 and 20 WAP

DVL1, DVL2, DVBR1, DVBR2 are soil samples from 8 WAP (a), JVL1, JVL2, JVBR1, JVBR2 are soil samples from 12 WAP (b), FVL1, FVL2, FVBR1, FVBR2 are soil samples from 16 WAP (c), MVL1, MVL2, MVBR1, MVBR2 are soil samples from 20 WAP (d), D=December; J=January; F=February; $\mathrm{M}=\mathrm{March}$; VL and VBR=Variety of Bambara from whose root soil samples were taken

Furthermore, Figure 4 (a) revealed that CEC and Ca were the highest mineral found in the soil samples and both were found in DVL2 and DVBR2 while NO3 had decreased and total N is seen to increase from the previous weeks where it was absent in all samples. (b) showed that CEC and NO3 were the highest mineral found in the soil samples and both were found in JVL1 and JVL2 (c) showed that CEC is highest and found in FVBR1 while $\mathrm{NO}_{3}$ has decreased again but available in all samples. (d) showed that CEC is highest and found in MVBR1 while $\mathrm{NO}_{3}$ has gradually increased again and available in all samples. Also total $\mathrm{N}$ increased and consistent in b, c, d samples.

\subsection{2 pH and Redox tolerance of soil samples}

The different soils at the different growth stages differed in their physical and chemical properties. The $\mathrm{pH}$ reduced gradually from the original bulk soil to the soil at the time of harvest. The $\mathrm{pH}$ ranged from 2.3 at 16 WAP which was the lowest, to 3.4 at 12 WAP which was the highest. The reduction-oxidation relationship of both living and non-living things is measured by the redox potential (Eh) measured in volts. The Eh in this study ranged from $170.33 \mathrm{mV}$ at $12 \mathrm{WAP}$ to $221.67 \mathrm{mV}$ at $16 \mathrm{WAP}$. This pattern of Eh and $\mathrm{pH}$ shows that they are both negatively correlated. This result reveals that nitrogen fixation by root nodule 
bacteria and activities of rhizospheric bacteria can affect the condition of the soil from one season to the other (Fig. 5a and Fig. 5b). Also though redox value, $<300 \mathrm{mV}$ can be limiting for plant growth but bambara groundnut has grown and also increased in yield.

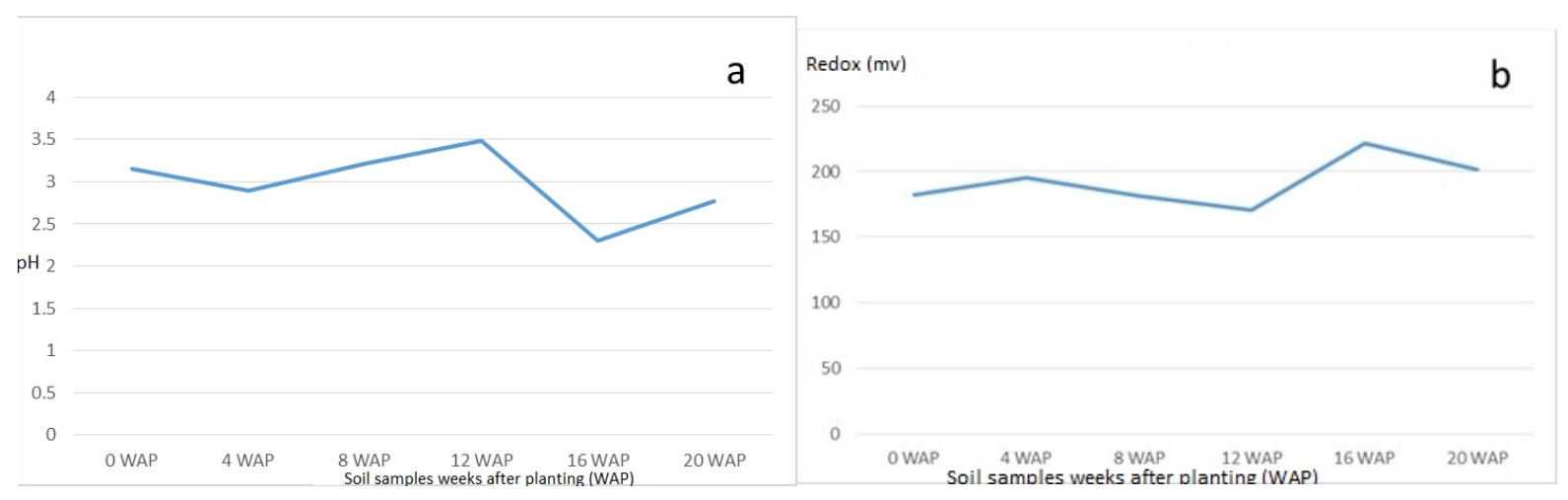

Figure 5: (a) Average $\mathrm{pH}$ values of soil samples from original soil to the time harvest. The highest $\mathrm{pH}$ was at 12 WAP while the least was at 16 WAP. (b) Average Redox value for soil samples at the different growth stages from original soil to the time harvest. The highest value was at $16 \mathrm{WAP}$ while the lowest was at 12 WAP. The line graph for redox and $\mathrm{pH}$ are inversely related.

\subsection{Organic matter content of soil samples}

The organic matter of soils varies based on the type of soil. The organic matter in this study ranged from $2.02 \%$ at 0 WAP (bulk soil) which is the lowest to $3.46 \%$ which is the highest at $16 \mathrm{WAP}$. The organic matter kept increasing form 4 WAP to $16 \mathrm{WAP}$ and reduced at the time of harvest. Total organic carbon also followed the same pattern as the total organic matter. It ranged from $1.18 \%$ at 0 WAP which was the lowest to $20.01 \%$ at $16 \mathrm{WAP}$ which was the highest (Figure 6). 


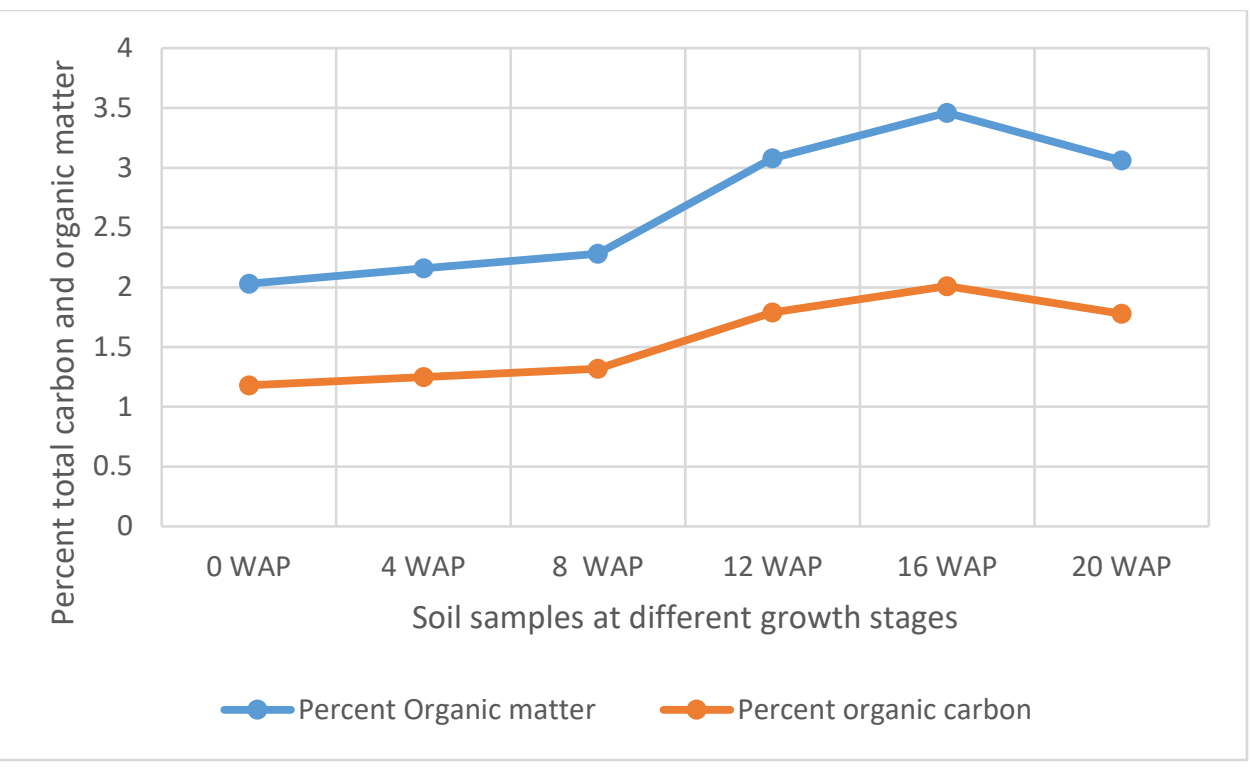

Figure 6: Carbon and organic matter content of soil samples from 0 WAP to harvest (20 WAP)

\subsection{Culturing and isolation of bacteria from soil samples}

The 43 isolates subcultured spanned through the different growing seasons. Some isolates that grew at the beginning of the growth period were also isolated at harvest while most of them were not. Most of the organisms isolated at the time of harvest were not the same as those that were there from beginning. The number of isolates increased from 4 WAP to 8 WAP only to decrease at 12 WAP and then continued increasing up till the time of harvest. The period of the $12 \mathrm{WAP}$ corresponded to the pod and seed formation period (Table 1). 
Table 1: Total number of different isolates by morphology at different growth stages

\begin{tabular}{|c|c|c|c|c|c|c|c|c|c|}
\hline \multirow{2}{*}{\multicolumn{2}{|c|}{ Soil Samples }} & \multicolumn{2}{|c|}{ Soil Samples } & \multicolumn{2}{|c|}{ Soil Samples } & \multicolumn{2}{|l|}{ Soil Samples (16 } & \multicolumn{2}{|l|}{ Soil Samples (20 } \\
\hline & & (8 WAP) & $*$ NOI & (12 WAP) & *NOI & WAP) & *NOI & WAP/harvest) & *NOI \\
\hline NVL 1 & 3 & DVL 1 & 5 & JVL 1 & 3 & FVL 1 & 3 & MVL 1 & 22 \\
\hline NVBR 1 & 2 & DVBR 1 & 9 & JVBR 1 & 2 & FVBR 1 & 4 & MVBR 1 & 17 \\
\hline NVL2 & 8 & DVL2 & 8 & JVL2 & 5 & FVL2 & 11 & MVL2 & 8 \\
\hline NVBR2 & - & DVBR2 & 2 & JVBR2 & 3 & FVBR2 & 4 & MVBR2 & - \\
\hline Total & 13 & & 24 & & 13 & & 22 & & 47 \\
\hline
\end{tabular}

*NOI is number of isolates 


\subsection{PGPR activities}

From the PGPR tests, $41.87 \%$ (18) showed positive actions in two or more of the PGP tests. Out of which $4.65 \%$ of the isolates were positive for $\mathrm{HCN}$ production, all were positive for $\mathrm{NH}_{3}$ production and ACC with absorbance at $570 \mathrm{~nm}$ and standard curve was drawn (Fig 7a and Fig 7b). Isolates that were positive for IAA production were $16.28 \%$. Absorbance value was recorded for all organisms (Fig 8a) and 27.91\% solubilized phosphate (Table 2). Standard curve for IAA was also plotted (Fig 8b). This was used to calculate the quantity of IAA produced by each isolate (Appendix). Of all the isolates, $27.91 \%$ showed positive activity for catalase, oxidase and protease production but the isolates that were positive in at least two of the PGP tests were all positive in at least one of the biochemical test while $13.95 \%$ of the isolates that were not positive to at least 2 of the PGP tests were positive to all the 3 biochemical tests (Table 3 ). While out of the 18 isolates used in this study, $27.77 \%$ were positive to catalase, oxidase and protease production.

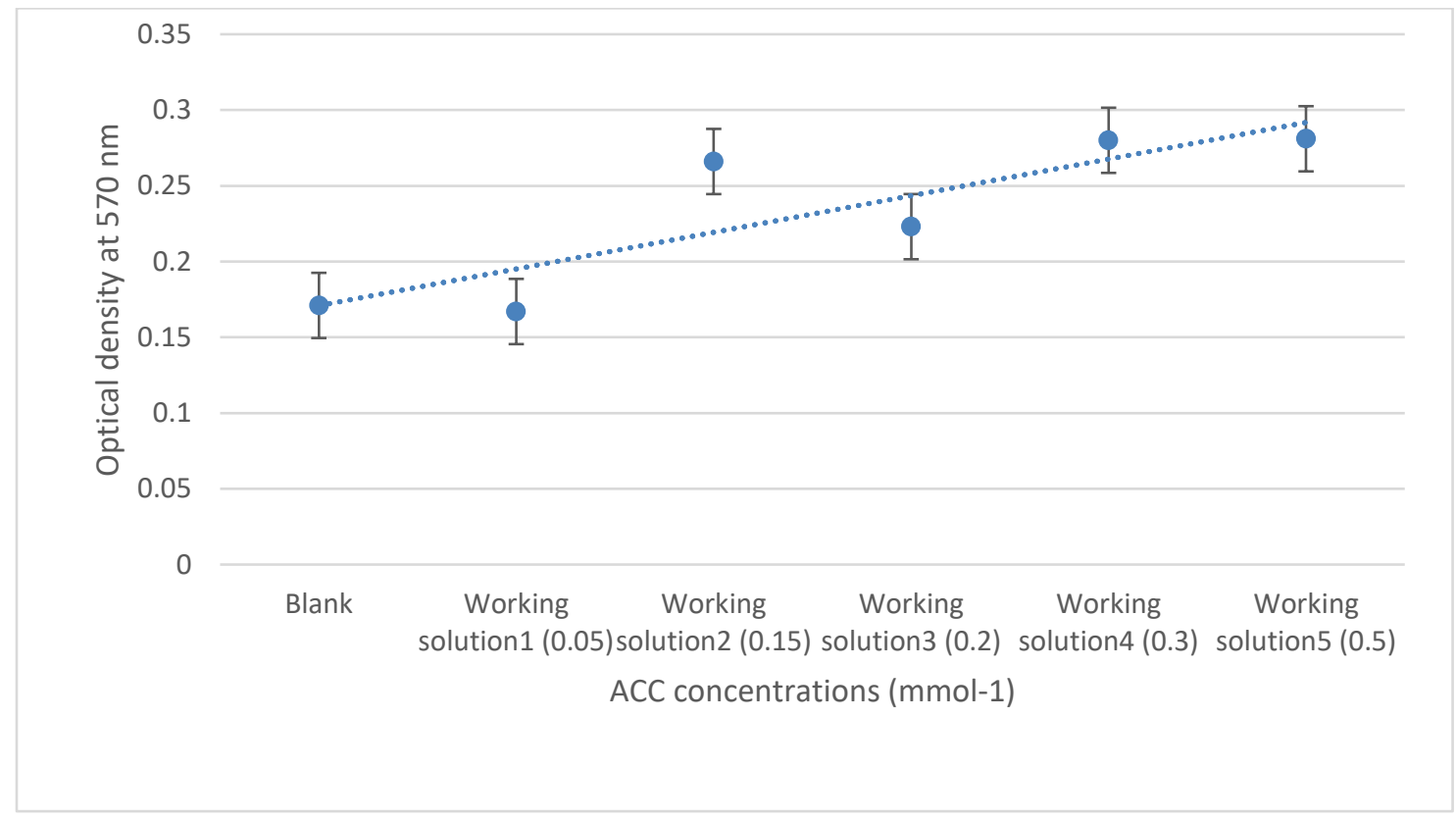

Figure 7a: Standard curve of ACC concentrations ranging from 0.05 to $0.5 \mathrm{mmol}^{-1}$ determined by the 96 well PCR-plate ninhydrin assay $\left(y=0.0242 x+0.1467, R^{2}=0.7364\right)$. Each data point represents the mean from triplicate determinations, and the error bar represents the standard error ACC, 1-aminocyclopropane1-carboxylate. 


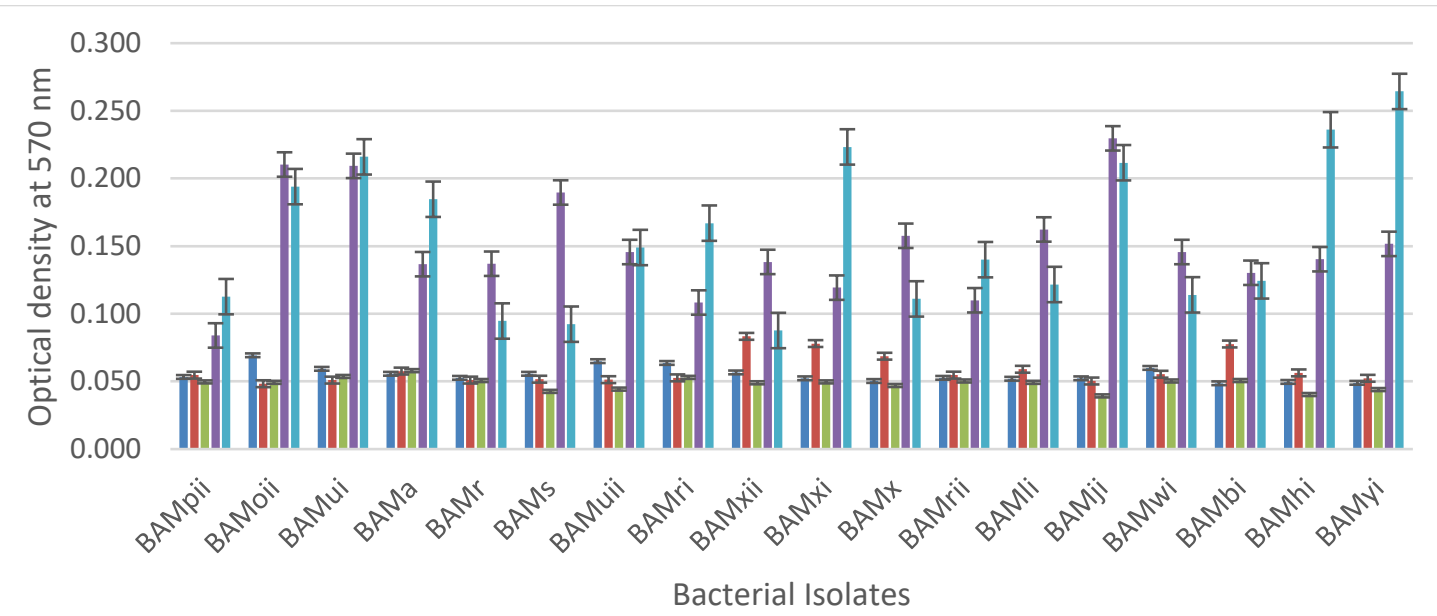

absorbance $0.05 \mathrm{mmol}-1$ Absorbance $0.15 \mathrm{mmol}-1$ Absorbance $0.2 \mathrm{mmol}-1$

absorbance 0.3 mmol-1 Absorbance 0.5 mmol-1

Figure 7b: Absorbance of bacterial isolates at different concentration of ACC

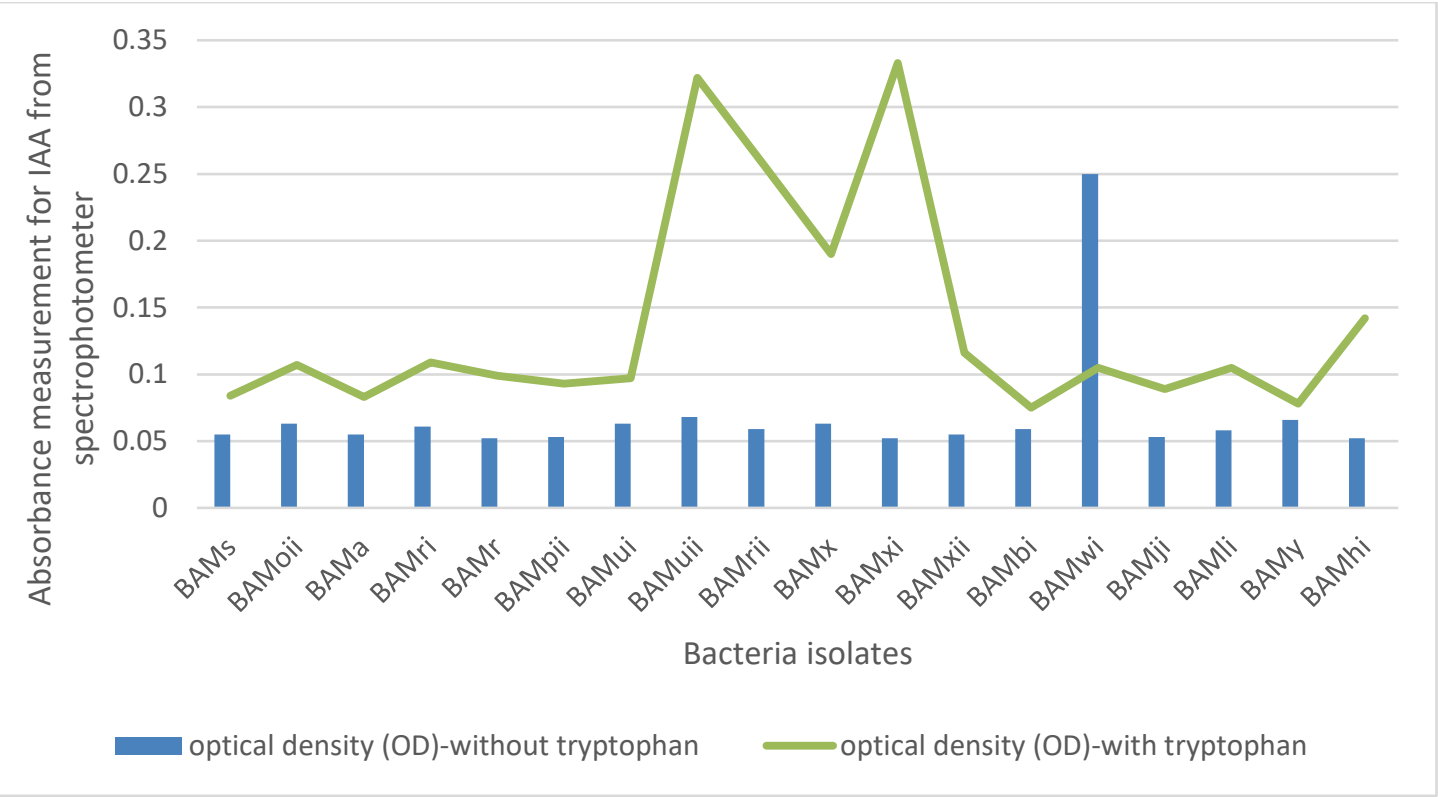

Figure 8a: Spectrophotometric measurement of absorbance of IAA in Isolates in the presence or absence of tryptophan at optical density of $530 \mathrm{~nm}$ 


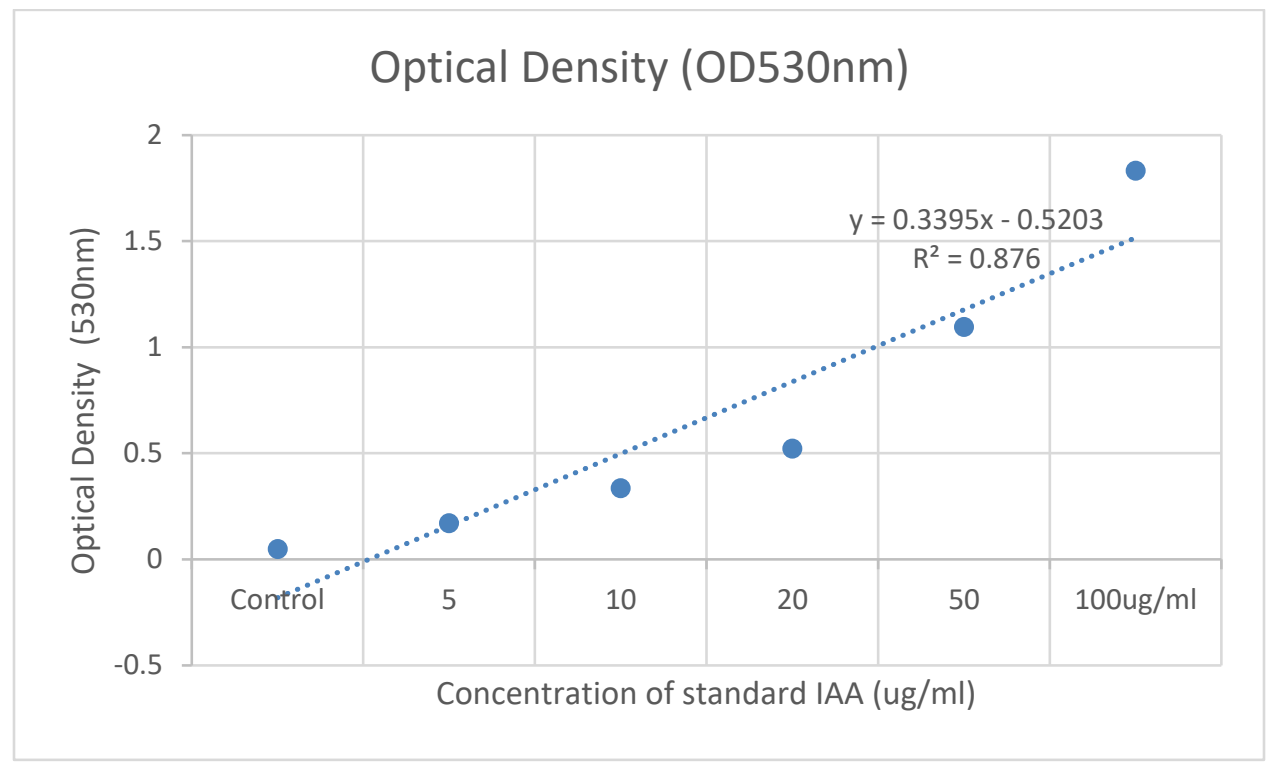

Figure 8b: Standard graph of IAA at optical density of 530nm

Table 2: Plant growth-promoting activities of rhizobacteria isolates from the above-mentioned soil samples

\begin{tabular}{|c|c|c|c|c|}
\hline Isolates & IAA & $\mathrm{NH}_{3}$ production & HCN & P-solubilization \\
\hline BAMxi & + & ++ & - & ++ \\
\hline BAMyi & - & + & - & ++ \\
\hline BAMpii & + & + & - & - \\
\hline BAMwi & + & + & - & - \\
\hline BAMri & + & + & - & - \\
\hline BAMoii & + & + & - & - \\
\hline BAMxii & + & ++ & - & ++ \\
\hline BAMuii & + & + & - & - \\
\hline BAMr & - & + & - & + \\
\hline BAMs & - & + & - & + \\
\hline BAMhi & - & + & + & + \\
\hline BAMli & - & ++ & - & + \\
\hline BAMx & - & + & - & + \\
\hline BAMa & - & + & - & ++ \\
\hline BAMbi & - & + & - & ++ \\
\hline BAMji & - & ++ & - & + \\
\hline BAMui & - & + & + & - \\
\hline
\end{tabular}




\begin{tabular}{|l|l|l|l|l|} 
BAMrii & - & + & - & + \\
\hline
\end{tabular}

BAM means isolates are from Bambara groundnut rhizosphere while the letters represents the different isolates

+ means positive; - means negative, ++ means very positive

Table 3: Biochemical activities of bacterial isolates from Bambara groundnut rhizosphere

\begin{tabular}{llll}
\hline Isolates & Catalase & Oxidase & Protease \\
\hline BAMxi & + & + & - \\
BAMyi & ++ & - & - \\
BAMpii & + & + & - \\
BAMwi & + & + & - \\
BAMri & + & - & - \\
BAMoii & + & + & - \\
BAMxii & + & + & - \\
BAMuii & ++ & - & - \\
BAMr & ++ & + & + \\
BAMs & ++ & + & + \\
BAMhi & + & - & - \\
BAMli & ++ & + & + \\
BAMx & - & + & + \\
BAMa & + & - & - \\
BAMbi & + & + & + \\
BAMji & + & - & - \\
BAMui & + & - & - \\
BAMrii & + & + & + \\
\hline BAM mean & + & + & +
\end{tabular}

$\overline{\text { BAM means isolates are from bambara groundnut rhizosphere while the letters represents the different }}$ isolates

+ means positive; - means negative, ++ means very positive

\subsection{Biocontrol activities}

Biocontrol activities were carried out in this study to test for the antifungal and antibacterial potentials of the bacterial isolates. 


\subsubsection{Antifungal activities}

Isolated bacteria were tested against Fusarium graminearum (written as f.g on the plate). BAMji, BAMr, BAMli and BAMhi (9.3\%) (B. cereus, B. amyloliquefaciens, B. thuringiensis, Bacillus sp.) showed antifungal potential against $F$. graminearum (Fig. 9).

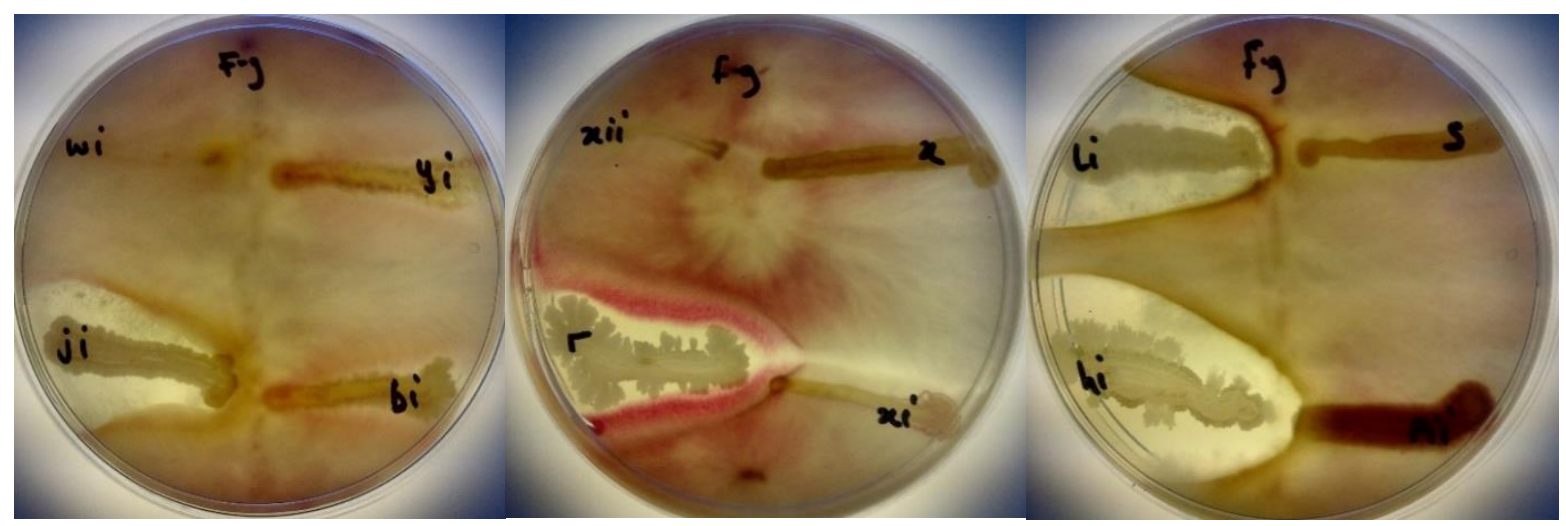

Figure 9: Antifungal activities of BAMji, BAMr, BAMli and BAMhi against $F$. graminearum (Source: Ajilogba and Babalola 2019)

\subsubsection{Antibacterial activities}

Rhizobacteria from this study were tested against B. cereus (written as B.C on the plates) and E. faecalis (written as E.F on the plates). BAMui, BAMli, BAMoii, BAMyi, BAMhi, and BAMpii (16.2\%) had antagonistic effects against $B$. cereus and $E$. faecalis as seen in the pattern formed on the streaked pathogen (Fig. 10).

\subsection{Molecular identification of selected isolates}

Bacterial universal primers (F1R2) amplified $1.5 \mathrm{~kb}$ fragment from the genomic DNA of the isolates. Computational analysis was used as a means of identifying the isolates. Analysis of the partial sequences of the 16S rDNA gene of the selected isolates was used as a means of identifying them at the genus level. The BLAST tool was used to compare the partial nucleotide sequences of the 16S rDNA gene of the isolates with the nucleotide database of NCBI web server. From the BLAST search, it was inferred that the isolates were members of the GC-rich firmicutes, actinobacteria and proteobacteria.

The 16S rDNA gene sequence of the selected isolates was obtained by BLASTn search; however, 27 strains of combination of the phylum firmicutes, actinobacteria and proteobacteria were selected based on high identity (\%) with good $\mathrm{E}$ value. Table 4 results show that query sequences were best pairwise aligned with 16S rDNA gene sequence of other firmicutes, proteobacteria and actinobacteria with sequence similarity and identity ranged between 96-99\%, with E-value of 0 . 


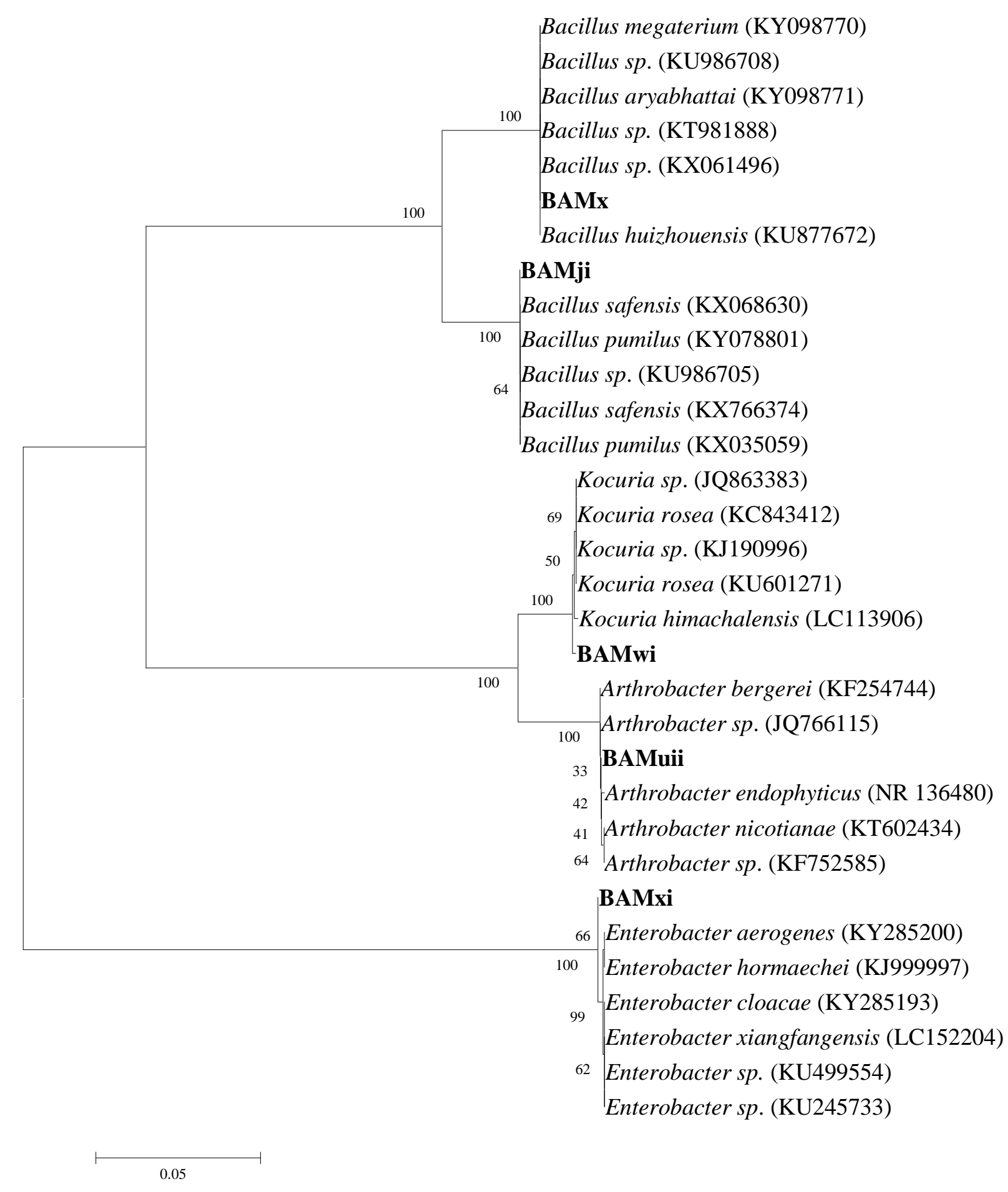

Figure 10: Phylogenetic tree based on 16S rRNA sequences using neighbour-joining method for bacterial isolates and their closely related type strains. 
Table 4: Results of 16S rDNA gene sequence similarities of rhizobacteria isolates and GenBank accession numbers using BLASTn algorithm isolate code

\begin{tabular}{|c|c|c|c|c|c|}
\hline $\begin{array}{l}\text { Isolate } \\
\text { code }\end{array}$ & $\begin{array}{l}\text { Sequence } \\
\text { length (bp) }\end{array}$ & Closest related strain in database & $\begin{array}{l}\text { Accession } \\
\text { number }\end{array}$ & $\begin{array}{l}\text { Similarity } \\
(\%)\end{array}$ & $\begin{array}{l}\text { E- } \\
\text { value }\end{array}$ \\
\hline BAMji & 1424 & B. cereus & KX588094 & 99 & 0 \\
\hline BAMr & 1058 & Bacillus sp. & KX588095 & 98 & 0 \\
\hline BAMui & 1405 & Bacillus sp. & KX588096 & 97 & 0 \\
\hline BAMx & 1417 & B. megaterium & KX588099 & 99 & 0 \\
\hline BAMuii & 1353 & $\begin{array}{l}\text { Glutamicibacter (Arthrobacter) } \\
\text { bergerei }\end{array}$ & KX588097 & 98 & 0 \\
\hline BAMwi & 1335 & Kocuria rosea & KX588098 & 99 & 0 \\
\hline BAMxi & 1377 & Enterobacter hormaechei & KX588100 & 99 & 0 \\
\hline BAMa & 1387 & Staphylococcus sp. & KX588093 & 96 & 0 \\
\hline
\end{tabular}

\subsection{Phylogenetic analysis and diversity}

The isolates were subjected to phylogenetic analysis. The 16S rDNA sequences of the bacterial isolates were aligned with reference nucleotide sequences obtained from the GenBank. The phylogenetic position of the bacterial isolates was evaluated by constructing a phylogenetic tree using neighbour joining method (Fig. 11). This method placed the bacterial isolates in different clades encompassing members of their genera; this was supported with bootstrap values. Bootstrap values based on 1000 replications were listed as percentages at the branching points.
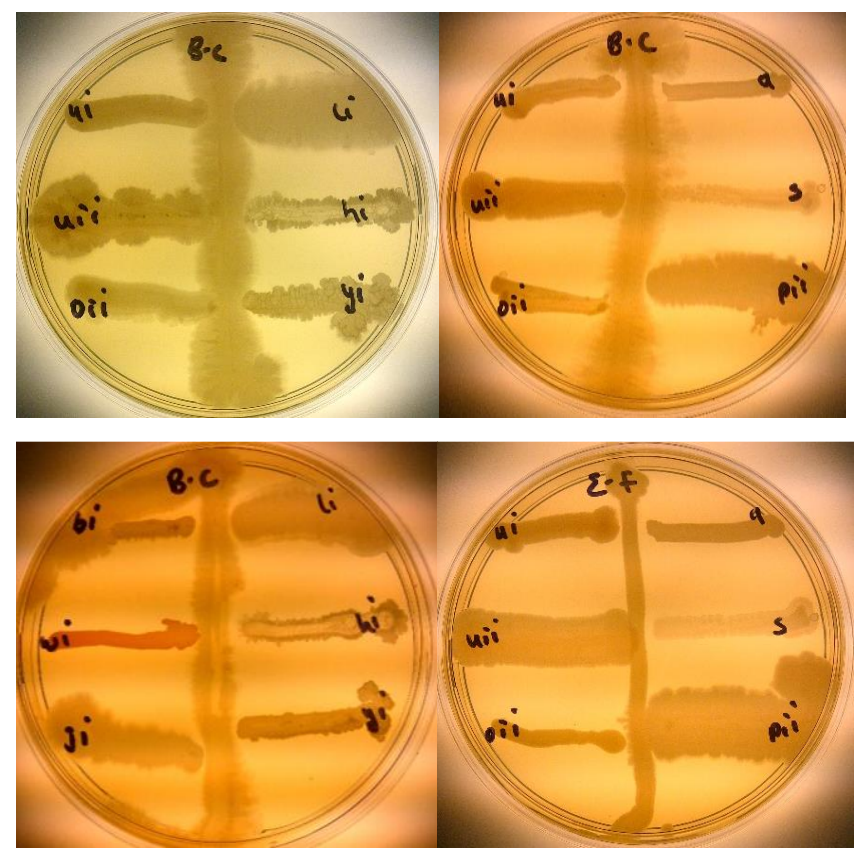
Figure 11 Antibacterial activities of isolates BAMui, BAMli, BAMoii, BAMyi, BAMhi, and BAMpii against B. cereus and E. faecalis

\subsection{Discussion}

The plants' rhizosphere, especially those of legumes, have been observed to be a microbiome for diverse PGPR. Bambara groundnut as a legminous plant is not only good for food but its rhizosphere is also very important in promoting plant growth and increasing food production. The rhizosphere is rich in total nitrogen, nitrate and CEC. In this study, the highest nitrate and CEC values were $26.16 \mathrm{cmol} / \mathrm{kg}$ at $4 \mathrm{WAP}$ and $21.64 \mathrm{meq} / 100 \mathrm{~g}$ at $12 \mathrm{WAP}$ respectively while the least values were $6.28 \mathrm{cmol} / \mathrm{kg}$ and $15.19 \mathrm{meq} / 100 \mathrm{~g}$ both at 8 WAP respectively (Fig. 4.3). The nitrate available in the soil falls in the same range with the soil nitrate analysed at different growing season from Dobra Voda and Chvalina farms during Spring and Autumn ranging between 4 and $14 \mathrm{ppm} \mathrm{N}$, though some of the values from this study are higher [26]. These higher values of nitrate can be as a result of bambara groundnut's ability to fix nitrogen through symbiosis with the bacteria in the root nodules. According to Vaněk, Šilha and Němeček [26], it can also be as result of the activities of leguminous crops in which case bambara groundnut is one. The CEC of soil samples in this study (between 15.19 and $21.64 \mathrm{meq} / 100 \mathrm{~g}$ ) fall within the range of CEC of organically and conventionally managed apple orchard ranging from 19.23 to $20.28 \mathrm{cmol} / \mathrm{kg}$ [27], even though no fertilizer or organic manure was applied to bambara groundnut in this study.

The variation in the physical and chemical composition of the soil at different growth stages of bambara groundnut shows the involvement of these rhizobacteria in nitrification (Fig. 3, Fig. 4 and Fig. 5). This is because as the number of rhizobacteria increases (Table 1), the $\mathrm{cmol} / \mathrm{kg}$ of nitrate decreases, this could be as a result of uptake of nitrate by plants through the rhizobacteria [28]. As the number of rhizobacteria increases, the usage of $\mathrm{NO}_{3}$ increases by the plant and so its availability in the soil decreases. This is in agreement with the observation made that with an increase of PGPR in the soil, plant uptake of nitrogen from fertlizer applied to the soil also increases [29]. This is obvious in $8 \mathrm{WAP}$ and $16 \mathrm{WAP}$ where the number of isolates were high but the volume of $\mathrm{NO}_{3}$ and other CEC were low. It could also mean that though the rhizobacteria were available in the soil they might not be nitrogen fixers. Nitrogen available in the soil can also be low if plant density is low since both are positively correlated and might not be as a result of poor symbiotic relationship [30]. This was contrary to other findings which observed that nitrogen increased with increase in microbial population and activities [31]. In the $12 \mathrm{WAP}$, when $\mathrm{NO}_{3}$ was very high but number of isolates was low, it corresponded to the period of pod and seed formation. This helps to shed more light on the reason for the increase in $\mathrm{NO}_{3}$ and also if the type of rhizobacterial available were nitrogen fixers or the number of nitrogen fixers increased in the soil at this growth stage. Apart from 
nitrogen-fixers being in the nodules there are other free living rhizobacteria that are non-symbionts, free living in the rhizosphere and can also fix nitrogen [32] even though in small amounts [33].

Normally, leguminous plants are sensitive to $\mathrm{pH}$ and this is important to their nitrogen-fixing ability because at low $\mathrm{pH}$ the soil is acidic and inhibits the activities of nitrogen-fixing bacteria and nitrogen is not released for plant growth [34]. Bambara groundnut grows well on acidic soils [35] which agrees with the result from this study. It was observed that there was an increase in alfalfa yield when there was no additional nitrogen and the $\mathrm{pH}$ was high which is in contrast to the observation in this study. Although the $\mathrm{pH}$ of the soils throughout the season were acidic as they ranged from 2.3 to 3.49 , nitrogen was available in the form of nitrate as mentioned earlier and bambara groundnut was enhanced in growth. Out of 12 isolates from the root nodule of bambara groundnut isolated from Cameroonian soil, 8 of them were able to grow at $\mathrm{pH} 3.5$ in the soil which was acidic. This also reveals the potential of bambara groundnut to grow under very harsh condition [36]. Soil pH and redox potential (Eh) are negatively correlated, as one increases the other decreases. The Eh in this study ranged from 170.33 to $221.66 \mathrm{mV}$ which falls into the category of moderately reduced soils having Eh between +100 and $+400 \mathrm{mV}$ and close to cultivated soils with Eh range of between +300 and $+500 \mathrm{mV}$ [37]. The $\mathrm{Eh}$ and $\mathrm{pH}$ of the soil help to determine the type of metabolism evident in the bacterial community of the soil and invariably the biological activities of the soil. Growth and development of soil bacteria and their metabolic, enzymatic and microbial activities are directly or indirectly affected by the Eh and/or the $\mathrm{pH}[38,39]$.

Soil organic matter in the soil is very vital and important as it can produce as much carbon found in the combination of that of the atmosphere as carbon dioxide and the biomass of plants [40]. In this study, the soil organic matter increased till 16 WAP and decreased at harvest, this could be as a result of heavy metabolic processes involving pod and seed formation at the 12 and 16 WAP. Assertion from this study points to the fact that between $4 \mathrm{WAP}$ and $16 \mathrm{WAP}$, the soil of Bambara groundnut kept increasing and at 16 WAP experienced the highest level of fertility. At this point, other cereals can be cropped with Bambara groundnut to improve their growth.

Bacteria from the rhizosphere are important in auxin production and vitamin synthesis that encourage biofertilization [41]. Bacterial isolates from this study were able to produce IAA and solubilise phosphate which are important in biofertilization to increase crop growth. Ammonia, HCN and siderophore production and phosphate solubilization are also able to contribute to biocontrol potentials of rhizobacteria [21]. Seventy eight percent $(78 \%)$ of the isolates from different monocotyledonic plants' rhizosphere and soil [21], 77.1\% of isolates from chickpea rhizosphere [42], 85.57\% of isolates from maize rhizosphere [43] produced ammonia as against $100 \%$ ammonia production from this study. This could be as a result of the high nitogen-fixing capacity of both the nitrogen fixers and free living non-symbionts in the rhizosphere of bambara groundnut. 
Soil phosphorous is an important macronutrient needed for plants to grow, hence deficiency of Phosphorus in soil is a major challenge in agricultural food/crop production. Total soil $\mathrm{P}$ occurs in either organic or inorganic form. The major form of organic phosphorus in the soil is phytate (salts of phytic acid). As a source of phosphorus, it constitutes about $60 \%$ of soil organicphosphorus and this organic form is poorly utilized by plants [44]. It either forms a complex with cations or adsorbs to various soil components, so it is not readily available to plants. For phytate-P to be immobilized so that it is easily utilized by plants, phytate has to be solubilized. Phytate can then be dephosphorylated by phosphatases (phytases and phosphatases) before it is assimilated by plants [45]. Some soil microorganisms secrete phytases into the soil to be able to make use of organic substances from plants roots and also when they compete with plant roots for elements such as phosphorus [46]. The phytases secreted into the rhizosphere invariably help to immobilize phytate and make it soluble so that it is utilised by the plants [47].

Phosphate solubilization is a complex phenomenon and it helps to discriminatively screen the bacteria which are able to break down tricalcium phosphate (TCP) and thereby release inorganic phosphate. According to Laslo, György, Mara, Tamás, Ábrahám and Lányi [21], 63.8\% of bacteria isolates from different rhizosphere of monocotyledonous plants solubilized phosphate as against $27.91 \%$ from this study. It was observed that none of the isolates from fields growing chickpea from West of Allahabad Agricultural Institute, India produced $\mathrm{HCN}$ [42] while in this study $4.65 \%$ produced $\mathrm{HCN}$. This result is not comparable to a report by Agbodjato, Noumavo, Baba-Moussa, Salami, Sina, Sèzan, Bankolé, Adjanohoun and BabaMoussa [43] which revealed that $100 \%$ of isolates from maize rhizosphere produced HCN.

Isolates B. cereus, B. amyloliquefaciens, B. thuringiensis, Bacillus sp. from this study were able to antagonise the growth of $F$. graminaerum, which is an agricultural challenge to barley, wheat and maize in South Africa [48, 49]. It was observed that B. amyloliquefaciens produced HCN in addition to ammonia and solubilizing phosphate while B. cereus, B. thuringiensis and Bacillus sp. produced ammonia and solubilised phosphate. Isolates BAMui, BAMoii, BAMyi, BAMpii, B. amyloliquefaciens and $B$. thuringiensis. were able to antagonise the growth of B. cereus and E. faecalis. Three of the antifungal isolates also displayed antibacterial activities which show that some rhizobacteria are both antifungal and antibacterial agents while the rest are just purely antibacterial. Lysobacter spp strains have been found to carry out both antimicrobial and antifungal activities against Pythium ultimum, Colletotrichum gloeosporioides, F. oxysporum, Botrytis cinerea, Rhizoctonia solani, Botryosphaeria dothidea and B. subtilis [30]. The ability of these isolates to be able to inhibit and/or suppress the growth of both fungi and bacteria implies the richness of the bambara groundnut rhizosphere and its ability to resist diseases and pests.

It is important to identify bacterial isolates at the species level as vital information concerning the organisms such as its novelty and its ability to produce bioactive compound is provided (Adegboye and Babalola, 
2012). The $16 \mathrm{~S}$ rDNA gene sequence analysis was used to identify selected bacterial isolates in this study. The comparison of the bacterial isolates sequences revealed 96-99\% identification similarities with $16 \mathrm{~S}$ rDNA gene sequence of the genus Bacillus, Enterobacter, Arthrobacter and Kocuria. The 16S rDNA gene sequences analysis has been shown to be a very effective tool in phylogenetic characterization of microorganisms (Thenmozhi and Kannabiran, 2010). This analysis is important as it helps to explain the evolutionary relationship that exist among microorganisms. The phylogenetic relationship of the potent bacterial isolates to known Bacillus, Arthrobacter, Enterobacter, and Kocuria spp was first estimated through a BLAST search of the GenBank database. In order to have analysis that is robust and reliable, the strains that are closest to the selected isolates were chosen and used for comparison of pairwise sequence and also for the phylogenetic tree construction. The selected bacterial isolates were grouped distinctly in different branches. Sometimes strains of bacteria that are grouped distinctly produce distinct microbial agents (Intra et al., 2011).

The analysis of 16S rRNA nucleotide sequences is used to determine higher taxonomic relationships of microorganisms [50]. The nucleotide sequences comparison of the bacterial isolates showed 99-100\% identification similarities with those of reference nucleotide sequences from the GenBank. The phylogenetic tool is a powerful method that helps to elucidate the evolutionary relationship among organisms [51]. The tree revealed that the bacterial isolates have a phylogeny that is well supported and completely resolved. It also shows high resolution of all inner branches. Overall, this phylogenetic tree with its high-level branching is in consonance with traditional systematic divisions. This is because organisms that belong to the same family or genus taxonomically are grouped into different species using the traditional systematic divisions.

\section{Relationship between Bambara groundnut physical and chemical analyses, pH, Eh, PGPR and biocontrol}

Bambara groundnut physical and chemical analyses in this study reveal that the soil is an acidic soil and the growth of Bambara groundnut in the soil makes it more acidic and that it can thrive in acidic soil. It has been observed that redox reaction is very important to the biocontrol activity of plant pathogen by rhizobacteria [37]. This, they do by generating reactive oxygen species (ROS) in the plant and this serves as an antagonistic response of the plant to the pathogen and indirectly stresses the pathogen [52]. Hydrogen peroxide and other signals like salicyclic and glutathione have been observed to increase the resistance of plants to pathogens [53]. The isolates in this study were also able to release hydrogen peroxide in the catalase reaction, which might have also enhanced their ability to resist pathogen growth. 


\subsection{Conclusion}

The rhizosphere of Bambara groundnut is very rich in terms of biotic and abiotic components. It is quite interesting that most studies on Bambara groundnut have been on its food production but not much in-depth study has gone into its rhizosphere which is able to enhance its food production potential and then take it to the next level. This study revealed that the physical and chemical properties of soil at different growth stages are different and they affected the number, types and diversities of bacteria of Bambara groundnut rhizosphere. The Eh and $\mathrm{pH}$ of the soil were very important in the diversity of the bacterial isolates from the rhizosphere. They affected the type and abundance of the bacterial isolates at each growth stage. They were also important in the biocontrol potential of bacterial isolates. It is also observed from this study that PGP activities of rhizobacteria from Bambara groundnut's rhizosphere is comparable to those of other legumes and crops. Also, that Bambara groundnut has great potentials in food security as biofertilizer and biocontrol agent against fungal and bacterial pathogens. These bacteria would be explored for their VOCs and how they can be used in other biotechnological processes.

\section{Acknowledgement}

We gratefully acknowledge the North-West University for bursary to the first author and the National Research Foundation, South Africa, for grant that supports work in our laboratory.

\section{Funding}

OOB is deeply appreciative of the seven years of National Research Foundation (NRF) incentive funding (UID81192).

\section{Conflict of Interest}

The authors declare that they have no conflict of interest.

\section{References}

1. Giuliani A, Hintermann F, Rojas W, Padulosi S (2012) Biodiversity of Andean grains: balancing market potential and sustainable livelihoods. Bioversity International, Rome.

2. Celine $\mathrm{M}$ (2010) Molecular, environmental and nutritional evaluation of bambara groundnut (Vigna subterranea (L) Verdc.) for food production in Namibia.

3. Brough SH, Azam-Ali SN (1992) The effect of soil moisture on the proximate composition of Bambara groundnut (Vigna subterranea (L) Verdc). Journal of the Science of Food and Agriculture 60: 197-203.

4. Hillocks R, Bennett C, Mponda O (2012) Bambara nut: A Review of utilisation, market potential and crop improvement. African Crop Science Journal 20: 1-16. 
5. Mubaiwa J, Fogliano V, Chidewe C, Linnemann AR (2017) Hard-to-cook phenomenon in bambara groundnut (Vigna subterranea (L.) Verdc.) processing: Options to improve its role in providing food security. Food Reviews International 33: 167-194.

6. Ijarotimi O (2008) Nutritional composition, microbial status, functional and sensory properties of infant diets formulated from cooking banana fruits (Musa spp, ABB genome) and fermented Bambara groundnut (Vigna subterranean L. Verdc) seeds. Nutrition \& Food Science 38: 325-340.

7. Pal KK, Gardener BM (2006) Biological Control of Plant Pathogens. The Plant Health Instructor 10: 1094.

8. Maheshwari DK (2013) Bacteria in agrobiology: disease management. Springer Science \& Business Media

9. Compant S, Duffy B, Nowak J, Clément C, Barka EA (2005) Use of plant growth-promoting bacteria for biocontrol of plant diseases: principles, mechanisms of action, and future prospects. Applied and environmental microbiology 71: 4951-4959.

10. ISO-11464 (2006) Soil quality - Pretreatment of samples for physico-chemical analysis. ISO, Switerland

11. EPA (1986) Environmental Protection Agency, 1986. Method 9080 - Cation exchange capacity of soils (ammonium acetate). www.epa.gov/epawaste/hazard/testmethods/sw846/.../methindx.pdf.

12. Chapman HD (1965) Cation-exchange Capacity. American Society of Agronomy Method of soil analysis, Part 2: Chemical and microbiological properties: 891-900.

13. Page AL, Miller RH, Keeney DR (1982) Methods of Soil Analysis, Part II. Chemical and Microbiological Properties. American Society of Agronomy - Soil Science Society of America, Madison, WI, USA.

14. Abollino O, Aceto M, Malandrino M, Mentasi E, Sarzanini C, Petrella F (2002) Heavy metals in agricultural soils from Piedmont, Italy. Distribution, speciation and chemometric data treatment. Chemosphere 49: 545-557.

15. Abdulkadir M, Waliyu S (2012) Screening and isolation of the soil bacteria for ability to produce antibiotics. European Journal of Applied Sciences 4: 211-215.

16. Cavaglieri L, Orlando J, Rodriquez MI, Chulze S, Etcheverry M (2005) Biocontrol of Bacillus subtilis against Fusarium verticilliodes in vitro and at maize root level. Research Microbiology 156: 748-754.

17. Castric PA (1975) Hydrogen cyanide, a secondary metabolite of Pseudomonas aeruginosa. Canadian Journal of Microbiology 21: 613-618.

18. Loper J, Schroth M (1986) Importance of siderophores in microbial interactions in the rhizosphereIron, Siderophores, and Plant Diseases. Springer, pp. 85-98 
19. Bric JM, Bostock RM, Silverstone SE (1991) Rapid in situ assay for indole acetic acid production by bacteria immobilized on a nitrocellulose membrane. Applied and Environmental Microbiology 57: 535-538.

20. Katznelson H, Bose B (1959) Metabolic activity and phosphate-dissolving capability of bacterial isolates from wheat roots, rhizosphere, and non-rhizosphere soil. Canadian Journal of Microbiology 5: 79-85.

21. Laslo É, György É, Mara G, Tamás É, Ábrahám B, Lányi S (2012) Screening of plant growth promoting rhizobacteria as potential microbial inoculants. Crop Protection 40: 43-48.

22. Maurhofer M, Keel C, Haas D, Défago G (1995) Influence of plant species on disease suppression by Pseudomonas fluorescens strain $\mathrm{CHAO}$ with enhanced antibiotic production. Plant Pathology 44: 40-50.

23. Murray R, Costilow RN, Nester E, Wood WA, Krieg NR, Phillips G (1981) Manual of methods for general bacteriology. American Society for Microbiology, Washington, DC

24. Tewari A, Abdullah S (2015) Bacillus cereus food poisoning: international and Indian perspective. Journal of food science and technology 52: 2500-2511.

25. Jha AK, Bais HP, Vivanco JM (2005) Enterococcus faecalis Mammalian Virulence-Related Factors Exhibit Potent Pathogenicity in the Arabidopsis thaliana Plant Model. Infection and Immunity 73: 464-475. doi: 10.1128/iai.73.1.464-475.2005

26. Vaněk V, Šilha J, Němeček R (2003) The level of soil nitrate content at different management of organic fertilizers application. Plant Soil and Environment 49: 197-202.

27. Gasparatos D, Roussos P, Christofilopoulou E, Haidouti C (2011) Comparative effects of organic and conventional apple orchard management on soil chemical properties and plant mineral content under Mediterranean climate conditions. Journal of Soil Science and Plant Nutrition 11: 105-117.

28. Mantelin S, Touraine B (2004) Plant growth-promoting bacteria and nitrate availability: Impacts on root development and nitrate uptake. Journal of Experimental Botany 55: 27-34.

29. Adesemoye A, Torbert H, Kloepper J (2010) Increased plant uptake of nitrogen from $15 \mathrm{~N}$-depleted fertilizer using plant growth-promoting rhizobacteria. Applied Soil Ecology 46: 54-58.

30. Mohale KC, Belane AK, Dakora FD (2014) Symbiotic N nutrition, C assimilation, and plant water use efficiency in Bambara groundnut (Vigna subterranea L. Verdc) grown in farmers' fields in South Africa, measured using 15N and 13C natural abundance. Biology and Fertility of Soils 50: 307-319.

31. Salama OAEBAEA (2011) Utilization of Biofertilizers Utilization of Biofertilizers and Organic Sources in and Organic Sources in Arable Soils under Saline Conditions Using Tracer Technique. Research, Al-Azhar University 
32. Ahemad M, Kibret M (2014) Mechanisms and applications of plant growth promoting rhizobacteria: Current perspective. Journal of King Saud University-Science 26: 1-20.

33. Glick BR (2012) Plant growth-promoting bacteria: mechanisms and applications. Scientifica 2012: 15 pages. doi: 10.6064/2012/963401

34. Beegle D (n.d) Soil fertility management for forage crops -Pre-establishment. In: University, PS (ed.) Agronomy Facts 31-A. Pennsylvania State University College of Agricultural Sciences Pennsylvania, USA.

35. Mkandawire CH (2007) Review of Bambara groundnut (Vigna subterranea (L.) Verdc.) production in Sub-Sahara Africa. Agricultural Journal 2: 464-470.

36. Laurette NN, Maxémilienne NB, Henri F, Souleymanou A, Kamdem K, Albert N, Dieudonné N, François-Xavier E (2015) Isolation and screening of indigenous Bambara groundnut (Vigna Subterranea) nodulating bacteria for their tolerance to some environmental stresses. American Journal of Microbiological Research 3: 65-75.

37. Husson O (2013) Redox potential (Eh) and pH as drivers of soil/plant/microorganism systems: a transdisciplinary overview pointing to integrative opportunities for agronomy. Plant and Soil 362: 389-417. doi: 10.1007/s11104-012-1429-7

38. Kimbrough DE, Kouame Y, Moheban P, Springthorpe S (2006) The effect of electrolysis and oxidation-reduction potential on microbial survival, growth, and disinfection. International Journal of Environment and Pollution 27: 211-221.

39. Marino D, Pucciariello C, Puppo A, Frendo P (2009) The redox state, a referee of the legumerhizobia symbiotic game. Advances in Botanical Research 52: 115-151.

40. Schimel DS (1995) Terrestrial ecosystems and the carbon-cycle. Global Change Biology 1: 77-91.

41. Babalola OO, Akindolire AM (2011) Identification of native rhizobacteria peculiar to selected food crops in Mmabatho municipality of South Africa. Biological Agriculture and Horticulture 27: 294309.

42. Joseph B, Ranjan Patra R, Lawrence R (2012) Characterization of plant growth promoting rhizobacteria associated with chickpea (Cicer arietinum L.). International Journal of Plant Production 1: 141-152.

43. Agbodjato NA, Noumavo PA, Baba-Moussa F, Salami HA, Sina H, Sèzan A, Bankolé H, Adjanohoun A, Baba-Moussa L (2015) Characterization of potential plant growth promoting rhizobacteria Isolated from maize (Zea mays L.) in Central and Northern Benin (West Africa). Applied and Environmental Soil Science 2015. 
44. Mudge SR, Smith FW, Richardson AE (2003) Root-specific and phosphate-regulated expression of phytase under the control of a phosphate transporter promoter enables Arabidopsis to grow on phytate as a sole P source. Plant Science 165: 871-878.

45. Richardson AE, Barea J-M, McNeill AM, Prigent-Combaret C (2009) Acquisition of phosphorus and nitrogen in the rhizosphere and plant growth promotion by microorganisms. Plant and soil 321 : 305-339.

46. Wasaki J, Maruyama H, Tanaka M, Yamamura T, Dateki H, Shinano T, Ito S, Osaki M (2009) Overexpression of the LASAP2 gene for secretory acid phosphatase in white lupin improves the phosphorus uptake and growth of tobacco plants. Soil science and plant nutrition 55: 107-113.

47. Singh B, Satyanarayana T (2011) Microbial phytases in phosphorus acquisition and plant growth promotion. Physiology and molecular biology of plants : an international journal of functional plant biology 17: 93-103. doi: 10.1007/s12298-011-0062-x

48. Boutigny A-L, Ward TJ, Ballois N, Iancu G, Ioos R (2014) Diversity of the Fusarium graminearum species complex on French cereals. European journal of plant pathology 138: 133-148.

49. van der Lee T, Zhang H, van Diepeningen A, Waalwijk C (2015) Biogeography of Fusarium graminearum species complex and chemotypes: a review. Food Additives \& Contaminants Part A, Chemistry, Analysis, Control, Exposure \& Risk Assessment 32: 453-460. doi: 10.1080/19440049.2014.984244

50. Yarza P, Yilmaz P, Pruesse E, Glöckner FO, Ludwig W, Schleifer K-H, Whitman WB, Euzéby J, Amann R, Rosselló-Móra R (2014) Uniting the classification of cultured and uncultured bacteria and archaea using 16S rRNA gene sequences. Nature Reviews Microbiology 12: 635-645.

51. Lau MC, Cameron C, Magnabosco C, Brown CT, Schilkey F, Grim S, Hendrickson S, Pullin M, Sherwood Lollar B, van Heerden E (2014) Phylogeny and phylogeography of functional genes shared among seven terrestrial subsurface metagenomes reveal $\mathrm{N}$-cycling and microbial evolutionary relationships. Frontiers in Microbiology 5: 531.

52. Hartmann A, Schmid M, Van Tuinen D, Berg G (2009) Plant-driven selection of microbes. Plant and Soil 321: 235-257.

53. Van Camp W, Van Montagu M, Inzé D (1998) $\mathrm{H}_{2} \mathrm{O}_{2}$ and NO: Redox signals in disease resistance. Trends in Plant Science 3: 330-334. doi: 10.1016/S1360-1385(98)01297-7 